Article

\title{
Synergistic Effects of Zinc Oxide Nanoparticles and Bacteria Reduce Heavy Metals Toxicity in Rice (Oryza sativa L.) Plant
}

\author{
Nazneen Akhtar ${ }^{1}$, Sehresh Khan ${ }^{1}$, Shafiq Ur Rehman ${ }^{2}$, Zia Ur Rehman ${ }^{1}$, Amana Khatoon ${ }^{3}$, Eui Shik Rha ${ }^{4, *}$ \\ and Muhammad Jamil ${ }^{1, *(1)}$
}

1 Department of Biotechnology and Genetic Engineering, Kohat University of Science \& Technology (KUST), Kohat 26000, Pakistan; nazneen_kht92@yahoo.com (N.A.); sehreshkhan91@yahoo.com (S.K.); ziamarwat77@gmail.com (Z.U.R.)

2 Department of Biology, University of Haripur, Haripur 22620, Pakistan; drshafiq@yahoo.com

3 Department of Environmental and Botanical Sciences, Kohat University of Science \& Technology (KUST), Kohat 26000, Pakistan; proteomics.sp@gmail.com

4 Department of Well-Being Resources, Sunchon National University, Suncheon 540-742, Korea

* Correspondence: euishik@scnu.ac.kr (E.S.R.); dr.jamil@kust.edu.pk (M.J.)

Citation: Akhtar, N.; Khan, S.;

Rehman, S.U.; Rehman, Z.U.;

Khatoon, A.; Rha, E.S.; Jamil, M. Synergistic Effects of Zinc Oxide Nanoparticles and Bacteria Reduce Heavy Metals Toxicity in Rice (Oryza sativa L.) Plant. Toxics 2021, 9, 113. https://doi.org/10.3390/toxics9050113

Academic Editor: Ilektra Sperdouli

Received: 1 April 2021

Accepted: 17 May 2021

Published: 20 May 2021

Publisher's Note: MDPI stays neutral with regard to jurisdictional claims in published maps and institutional affiliations.

\begin{abstract}
Heavy metals (HMs) are toxic elements which contaminate the water bodies in developing countries because of their excessive discharge from industrial zones. Rice (Oryza sativa L) crops are submerged for a longer period of time in water, so irrigation with HMs polluted water possesses toxic effects on plant growth. This study was initiated to observe the synergistic effect of bacteria (Bacillus cereus and Lysinibacillus macroides) and zinc oxide nanoparticles (ZnO NPs) (5, 10, 15, 20 and $25 \mathrm{mg} / \mathrm{L})$ on the rice that were grown in HMs contaminated water. Current findings have revealed that bacteria, along with $\mathrm{ZnO}$ NPs at lower concentration, showed maximum removal of HMs from polluted water at $\mathrm{pH} 8$ (90 $\mathrm{min})$ as compared with higher concentrations. Seeds primed with bacteria grown in $\mathrm{HM}$ polluted water containing ZnO NPs ( $5 \mathrm{mg} / \mathrm{L}$ ) showed reduced uptake of HMs in root, shoot and leaf, thus resulting in increased plant growth. Furthermore, their combined effects also reduced the bioaccumulation index and metallothionine (MTs) content and enhanced the tolerance index of plants. This study suggested that synergistic treatment of bacteria with lower concentrations of $\mathrm{ZnO}$ NPs helped plants to reduce heavy metal toxicity, especially $\mathrm{Pb}$ and $\mathrm{Cu}$, and enhanced plant growth.
\end{abstract}

Keywords: heavy metals; polluted water; synergistic; bacteria; nanoparticles

\section{Introduction}

Rapid increase in industrialization and anthropogenic activities has greatly contributed towards Heavy Metals (HMs) pollution in water which affects all aspects of the ecosystem [1]. Heavy metals are metals with relatively high density that are toxic in small (e.g., $\mathrm{Cd}, \mathrm{Pb}, \mathrm{Hg}$, As) or higher (e.g., $\mathrm{Cu}, \mathrm{Zn}, \mathrm{Co}$ ) concentrations [2]. In Pakistan, no sewage treatment plants are available, so crop irrigation with HM contaminated water results in metal accumulation in grains and other tissues of the plant [3]. It is evident from the literature [4] that water samples obtained from Hayatabad Industrial Estate (HIE), Peshawar, Pakistan, showed a higher level of HM contamination than quality standards should allow. Rice is the main staple food used by 2.7 billion people globally as a daily energy requirement. In Pakistan, its production is badly affected due to excesses of HM contamination in irrigated water [5]. Basically, HMs affect the biological systems of rice plants by altering several processes such as water, nutrients and oxygen uptake, and damage the chlorophyll synthesis pathway [6]. HMs damage the structure and quantity of seeds, the area of sugars grains, the cellular organelles, and also break the mitochondria, the nuclear envelope and damage the wall thickness of the plant cell [7]. Toxic metals disturb osmoregulation during the development process in plants by increasing osmolarity, reducing water potential, affecting the leaf area and transpiration level, and creating 
reactive oxygen species (ROS) by oxidative burst of the lipid membrane, protein, and DNA [8]. Plants protect themselves from the toxic effect of HMs by binding with metal binding proteins (metallothionein), and sequester it inside the vacuole [9]. Metallothionein (MTs) stress biomarkers in plants which are expressed during stressful (salinity, drought, temperature and heavy metal stress) environments [9]. In the past, various approaches were used to remediate HMs from water, such as ion exchange, precipitation, adsorption, reverse osmosis, and sedimentation, but these are more expensive and time-consuming techniques than biological methods [10]. Currently, two approaches are commonly used to remediate HMs in water: bioremediation and nano-remediation [11]. Bacteria remediate HMs from water by using specific detoxifying mechanism such as bio-transformation, bioaccumulation and bio-precipitation [12]. However, the solubilized and dispersed form of heavy metals in water cannot be easily and efficiently removed by bacteria [13]. Therefore, there was a great demand to use adsorbents with effective binding capability to heavy metals, which can subsequently help in remediation of HMs in wastewater. ZnO NPs are environmentally friendly adsorbents for the removal of HMs from water due to the different functional groups on the surface, which are exchanged with HM ions in water solutions and improved plant growth [14]. ZnO NPs interact with HMs by adopting the adsorption mechanism (at neutral PH, the surface of $\mathrm{ZnO}$ NPs was negative, thus increasing electrostatic interaction between NPs and metals ions) and breaking the water molecules into hydrogen and oxygen, which further change into superoxide $\mathrm{O}^{2-}$ and bind with $\mathrm{H}^{+}$to form $\mathrm{HO}_{2}$ radical [15]. At higher concentrations, these radicals react with $\mathrm{H}^{+}$ ions to produce $\mathrm{H}_{2} \mathrm{O}_{2}$, into the cell membrane, and can kill the bacteria [12-16]. Zinc oxide NPs at lower concentrations ( 5 and $10 \mathrm{mg} / \mathrm{L}$ ) are essential constituents for the growth of bacteria and have a positive effect on enzymes such as dehydrogenase, thiol peroxidase and glutathione reductase, which increase the resistance level of bacteria against HMs [17].

Bacteria also play a significant role in the enhancement of the phytoremediation potential of plants; e.g., bacterial-priming enhances the germination of seeds by utilizing minerals such as iron, phosphate, and nitrogen, preventing the plant from different diseases [18]. Seed priming with the Bacillus species improved seed germination because of the secretion of amino cyclopropane (1-carboxylic acid (ACC) deaminase) enzymes that work as growth hormones [10]. Bacillus species promote seed growth via two types of mechanism: firstly, increasing phosphorus uptakes and, secondly, by biosynthesis of phytohormones (auxins (IAA), cytokines, and gibberellins), surfactant, fencing, and lipo-peptides that protect the seeds from abiotic stress [19]. Furthermore, ZnO NPs at lower concentration have a significant positive effect on plant growth and act as fertilizer, having less solubility and less toxicity towards microbes and plants than at higher concentrations [20], dispersing and releasing $\mathrm{Zn}^{2+}$ ions (positive charge ions) which have a high binding affinity toward HMs [21]. A higher concentration of ZnO NPs causes cell membrane disruption and induces intracellular oxidative species to include hydrogen peroxide and toxic agents, which are harmful to bacteria [22]. A recent report showed that ZnO NPs and titanium oxide nanoparticles efficiently remediate toxic metals from soil and increase the photosynthesis and metabolic activity of Picochlorum spp. plants [13].

It was reported [23] that bacteria remediate HMs from polluted water, but to the best of our knowledge, there is no data available on the combined application of bacteria and $\mathrm{ZnO}$ NPs to enhance the remediation potential of plants against HMs. Therefore, it was hypothesized that the synergistic treatments of bacteria and nanoparticles may significantly improve the remediating potential of plants in the toxic environment. The current study investigates the significance of combined treatments of bacteria and nano-particles on plants raised from seeds primed with Bacillus spp. and grown in HM contaminated water, along with a lower concentration ( 5 and $10 \mathrm{mg} / \mathrm{L}$ ) of ZnO NPs, by using physiological, biochemical and heavy metal remediation, e.g., bioaccumulation and tolerance index methods. 


\section{Materials and Methods}

\subsection{Sampling}

Wastewater sample was collected from the Hayatabad industrial estate, Peshawar, Pakistan in clean and dry plastic bottles and placed at $4{ }^{\circ} \mathrm{C}$ in the Lab. ZnO NPs were characterized by Amara et al. [24] through Field Emission Scanning Electron Microscope (FESEM), Transmission Electron Microscopy (TEM), Fourier Transform Infrared Spectroscopy (FTIR), and X-ray diffraction (XRD) and obtained from Pir Mehr Ali Shah, Arid Agriculture University, Rawalpindi, Pakistan. The stock solution of ZnO NPs was prepared by dissolving $1 \mathrm{~g}$ of ZnO NPs in $1000 \mathrm{~mL}$ of sterilized (Milli-Q water) (Sigma-Aldrich, St. Louis, CA, USA). In order to break up large aggregates of NPs and obtain homogenized solutions, the ZnO NPs solution was placed in an ultrasonic bath for $30 \mathrm{~min}$. NPs were further sonicated for $30 \mathrm{~min}$ before each experiment.

\subsection{Bacterial Strains Collection and Cultivation}

The two HMs-resistant bacteria species (Bacillus cereus (PMBL-3) and Lysinibacillus macroides (PMBL-7), isolated from the industrial estate's effluent at Gadoon, were identified by Khattak et al. [25]. These two strains were obtained from the Plant and Microbial Biotechnology Laboratory, Kohat University of Science and Technology, Kohat, Pakistan. Bacterial strains were grown on nutrient broth (1\% tryptone (Sigma Aldrich, St. Louis, CA, USA) $1 \%$ sodium chloride (Sigma Aldrich, St. Louis, CA, USA), and 0.5\% yeast extract (Sigma Aldrich, St. Louis, CA, USA) at pH 7.4-7.6. Fresh culture of the bacteria was inoculated in autoclaved media for $24 \mathrm{~h}$. Afterwards, the culture broth containing bacteria was centrifuged at $3500 \times g$ for $10 \mathrm{~min}$, and then the pellet was properly washed with $1 \mathrm{~mL}$ of $5 \% \mathrm{NaCl}$ solution (Sigma Aldrich, St. Louis, CA, USA). The bacterial cells were suspended in sterilized saline water for further experiments.

\subsection{Heavy Metals Analysis in Polluted Water Samples}

Heavy metals $(\mathrm{Pb}, \mathrm{Cd}, \mathrm{Cr}$, and $\mathrm{Cu}$ ) content in polluted water was determined by following the methodology of Radulescu et al. [26]. HMs content was analyzed by adding $2 \mathrm{~mL}$ of $70 \%$ concentrated nitric acid $\left(\mathrm{HNO}_{3}\right)$ (Sigma Aldrich, St. Louis, CA, USA) and $5 \mathrm{~mL}$ of $50 \%$ concentrated hydrochloric acid ( $\mathrm{HCl}$ ) (Sigma Aldrich, St. Louis, CA, USA) in $(100 \mathrm{~mL})$ water samples boiled at $95^{\circ} \mathrm{C}$ on a hot plate (Ceramic hot plate C-MAG HP 4, Rawalpindi, Pakistan). Water was heated until the volume reduced to $15-20 \mathrm{~mL}$. HMs content was than analyzed by atomic absorption spectroscopy (Perkin Elmer, Analyst 4000, Waltham, MA, USA).

\subsection{Heavy Metals Remediation Analysis/Batch Culture Experiment}

\subsubsection{Heavy Metals Remediation in Artificially Polluted Water}

$\mathrm{HMs}(\mathrm{Pb}, \mathrm{Cd}, \mathrm{Cr}$, and $\mathrm{Cu})$ remediation of artificially polluted water $(100 \mathrm{mg} / \mathrm{L}$ of each metal) was carried out following the methodology of Bestawy [27]. Erlenmeyer flasks $(250 \mathrm{~mL})$ were filled with $100 \mathrm{~mL}$ of fresh bacteria strains culture (B. cereus and $L$. macroides), $\mathrm{HMs}(\mathrm{Pb}, \mathrm{Cd}, \mathrm{Cr}$, and $\mathrm{Cu}$ ) solution and different concentrations of ZnO NPs $(5,10,15,20$ and $25 \mathrm{mg} / \mathrm{L})$. Flasks were regularly agitated at $200 \mathrm{rpm}$ for $90 \mathrm{~min}$ in the shaker incubator until reaching equilibrium. Flasks were then centrifuged at $4000 \times g$ to separate the solid-liquid phase and the samples were filtered through a $0.22 \mu \mathrm{m}$ filter membrane. The experiment consisted of one positive control (bacteria culture without $\mathrm{ZnO}$ NPs) and one negative control (only ZnO NPs). All the experiments were performed in triplicate. HM concentrations in filtered water samples were determined by atomic absorption spectroscopy. HM removal efficiency (\%) was determined by the given formula [28]:

$$
\text { Removal Efficiencies }(\%)=\left(C_{0}-C_{e}\right) \times 100
$$

$\mathrm{C}_{0}$ is the initial while $\mathrm{C}_{\mathrm{e}}$ is the final concentration of HMs in solution. 


\subsubsection{Heavy Metals Remediation of Hayatabad Industrial Estate (HIE) Polluted Water}

The bio-nano remediation experiment further analyzed a polluted water sample designed in batch culture flasks by following the protocol of Bestawy [27] with slight modification. In this method, a series of $500 \mathrm{~mL}$ Erlenmeyer flasks were filled with $100 \mathrm{~mL}$ of polluted water with an equal volume $(100 \mathrm{~mL})$ of different concentrations of $\mathrm{ZnO} N P s(0$, $5,10,15,20$ and $25 \mathrm{mg} / \mathrm{L}$ ). Then $100 \mathrm{~mL}$ of fresh culture broth of B. cereus and L. macroides was added and agitated in incubator shaker at $200 \mathrm{rpm}(90 \mathrm{~min})$ until equilibrium was reached. The solution was centrifuged and the supernatant was used to investigate the $\mathrm{HM}(\mathrm{Pb}, \mathrm{Cd}, \mathrm{Cr}$ and $\mathrm{Cu})$ contents by atomic absorption spectroscopy.

\subsubsection{Heavy Metals Remediation at Different $\mathrm{pH}$ and Contact Time}

Effect of $\mathrm{pH}$ and contact time on the removal efficiency of HMs ions were determined by the following methodology [29]. Effect of $\mathrm{pH}$ was determined by mixing $100 \mathrm{~mL}$ of fresh cultured broth of bacteria strains (B. cereus and L. macroides) with $100 \mathrm{~mL}$ of metal ions (Sigma Aldrich, St. Louis, CA, USA) (Pb, Cd, Cr and Cu) $(100 \mathrm{mg} / \mathrm{L})$ solution and $100 \mathrm{~mL}$ of different concentrations of ZnO NPs (5, 10, 15, 20 and $25 \mathrm{mg} / \mathrm{L})$ solutions. All the flasks were agitated in a shaking incubator for $90 \mathrm{~min}$ at different $\mathrm{pH}(4,5,6.7$ and 8$)$ conditions. The $\mathrm{pH}$ of each solution was maintained by adding $1 \mathrm{~mL}$ of $5 \mathrm{M}$ hydrochloric acid $(\mathrm{HCl})$ and $1 \mathrm{~mL}$ of $5 \mathrm{M}$ sodium hydroxide (Sigma Aldrich, St. Louis, CA, USA) (NaOH). The $\mathrm{pH}$ of each flask was determined by $\mathrm{pH}$ meter (OAKIAN digital $\mathrm{pH}$ meter, Waltham, MA, USA). Further experiments were carried out at different time intervals (30, 60, 90, and $120 \mathrm{~min}$ ) while $\mathrm{pH}$ remained the same. Time at each interval was determined by Time clock (Time clipart digital clock, Waltham, MA, USA).

\subsection{Heavy Metals Remediation in Plants}

The remediation potential of the combined treatment of bacteria and ZnO NPs was further observed in the hydroponic culture experiment. Seeds were primed with bacterial strains (B. cereus and L. macroides) and grown in distilled water for 10 days. After 10 days, young seedlings were immediately transplanted in trays $(3 \mathrm{~L})$ containing one quarter strength Hoagland solution. The Hoagland medium composition includes $2.5 \mathrm{~mL}$ of $2 \mathrm{M}$ $\mathrm{KNO}_{3}, 2 \mathrm{~mL}$ of $2 \mathrm{M} \mathrm{Ca}\left(\mathrm{NO}_{3}\right)_{2} \times 4 \mathrm{H}_{2} \mathrm{O}, 1.5 \mathrm{~mL}$ of Iron oxide, $1 \mathrm{~mL}$ of $2 \mathrm{M} \mathrm{MgSO}_{4} \times 7$ $\mathrm{H}_{2} \mathrm{O}, 1 \mathrm{~mL}$ of $1 \mathrm{M} \mathrm{KH}_{2} \mathrm{PO}_{4}$, and $1 \mathrm{~mL}$ micronutrients. Plants were grown in the green house at $30 \pm 2{ }^{\circ} \mathrm{C}$ in $16 \mathrm{~h}$ light with $60 \%$ humidity. After 21 days of cultivation, seedlings were transferred from the Hoagland solution to the solutions containing 5 and $10 \mathrm{mg} / \mathrm{L}$ $\mathrm{ZnO} N \mathrm{Ns}$ in $(1 \mathrm{~L})$ and HM contaminated wastewater for 1 week (7 days). The hydroponic system was used to inhibit the sorption of ZnO NPs to the soil surface and ensure that NPs and HMs were fully available [21]. Three replicates for each treatment and control blank were grown. During the exposure time, plants were randomly rotated and relocated to ensure equal light exposure. After HM polluted water and ZnO NPs exposure, the $\mathrm{pH}$ of the growth medium was maintained with a $\mathrm{pH}$ meter every daily.

\subsubsection{Heavy Metals in Water and Plant Tissue (Root, Shoot and Leaf) after Remediation}

HM content in different tissues of the plant was investigated by following the protocol of Retka [30]. Plant tissues (root, shoot and leaves) were dried at $80^{\circ} \mathrm{C}$ in a dry oven (Dry heat Oven) for 2 days. Dried plant tissues $(0.5 \mathrm{~g})$ were taken and crushed with mortar and pestle separately. Crushed root, shoot, and leaf were digested with $3 \mathrm{~mL}$ of $70 \%(v / v)$ nitric acid and incubated overnight at room temperature. The next day, samples were heated at $95^{\circ} \mathrm{C}$ for $4 \mathrm{~h}$. After cooling, $2 \mathrm{~mL}$ of $30 \%(v / v) \mathrm{H}_{2} \mathrm{O}_{2}$ was added in the beaker and reheated at $95{ }^{\circ} \mathrm{C}$ until samples were fully digested. HM contents in different plant tissues were analyzed by atomic absorption spectroscopy (Perkin, ELMER, and Analyst 4000). 


\subsubsection{Heavy Metals Analysis in Polluted Water after Remediation Experiment}

Heavy metals $(\mathrm{Pb}, \mathrm{Cd}, \mathrm{Cr}$ and $\mathrm{Cu})$ content in polluted water was again analyzed by using the protocol of Radulescu [26]. To determine the HM content in treated water samples, $2 \mathrm{~mL}$ of concentrated nitric acid $\left(\mathrm{HNO}_{3}\right)$ and $5 \mathrm{~mL}$ of hydrochloric acid $(\mathrm{HCl})$ were added to the beaker. The solution was boiled on a hot plate (Ceramic hot plate C-MAG $\mathrm{HP}$ 4, Rawalpindi, Punjab, Pakistan) at $95^{\circ} \mathrm{C}$ until volume decreased to $15-20 \mathrm{~mL}$. HMs were determined by atomic absorption spectroscopy (Perkin Elmer, Analyst 4000, Waltham, MA, USA).

\subsection{Quantification of Low Molecular Weight Polypeptide Metallothioneins (MTs)}

Metallothionein content was quantified through spectroscopy by following the protocol as described previously by Palmiter et al. [31]. Plant samples were homogenized in a buffer solution containing $5 \mathrm{M}$ sucrose (Sigma-Aldrich, St. Louis, CA, USA), $20 \mathrm{mM}$ Tris- $\mathrm{HCl}$ (Sigma-Aldrich, St. Louis, CA, USA) (pH 8.6) and 0.01\% of $\beta$-mercapto-ethanol (Sigma-Aldrich, St. Louis, CA, USA). The mixtures were vortexed and spun at 10,000 rpm for $30 \mathrm{~min}$. Clear supernatant was taken and $1 \mathrm{~mL}$ chilled ethanol (Sigma Aldrich, St. Louis, CA, USA) was added. After 5 min, supernatant was mixed with $80 \mu \mathrm{L}$ chloroform (Sigma Aldrich, St. Louis, CA, USA). The solution was again spun in a micro-centrifuge at $6000 \mathrm{rpm}$ for $10 \mathrm{~min}$ (Micro centrifuge RM-03 plus, Waltham, MA, USA). Subsequently, $1 \mathrm{~mL}$ of cold $70 \%$ ethanol (ethyl) was mixed with supernatant and heated at room temperature (RT) for $1 \mathrm{~h}$ until the pellet was formed. Afterwards, a buffer solution (ethanol:chloroform in $87: 12 v / v$ ratio) was added into the pellet. Furthermore, $100 \mu \mathrm{L}$ of $5 \mathrm{mM}$ Tris- $\mathrm{HCl}$ and $1 \mathrm{mM}$ of ethylene diamine tetra-acetic acid (EDTA) ( $\mathrm{pH}$ 7) were added to the resulting pellet. In the resulting crude mixture of metallothioneins, $40 \mu \mathrm{L}$ of $0.43 \mathrm{mM}$ of nitrobenzoicacid ( $\mathrm{pH} 8$ ) and $5 \mu \mathrm{L}$ of $2 \mathrm{M}$ of phosphate buffer (PBS) was added for $30 \mathrm{~min}$ and the absorbance recorded at $412 \mathrm{~nm}$. The MTs activity was measured by the estimated curve of glutathione (GSH) with the following equation, assuming that $1 \mathrm{~mol}$ of MT contains $20 \mathrm{~mol}$ of cystein [31]:

Total glutathione $(\mathrm{GSSG}+\mathrm{GSH})=[\Delta \mathrm{OD}$ at $415 / \mathrm{min}-(\mathrm{y}$-intercept $)] \times$ sample dilution $\times 2$ *

* The equation is multiplied by 2 as 1 GSSG $=2$ GSH.

Metallothionein (MT) protein quantity was measured by the methodology of Tsugama et al. [32]. Plant material was boiled in $0.5 \mathrm{M}$ protein extraction buffer (Sigma-Aldrich, St. Louis, CA, USA) (1 mM EDTA (pH 8), 1 M of Tris-HCl (pH, 6.8), 10\% w/v SDS (SigmaAldrich, St. Louis, CA, USA), 100\% $\beta$-mercapto-ethanol and 80\% glycerol (Sigma-Aldrich, St. Louis, CA, USA) with a small amount of bromophenol blue (Sigma-Aldrich, St. Louis, USA). The solution was maintained at $\mathrm{pH} 7.4$ and placed for 5-10 min. Protein was estimated through Bradford's method by following the protocol as described previously by Laemmli [33]. The low molecular weight proteins of MTs were separated on a $17 \%$ SDS twin mini gel electrophoresis unit (Bio-Rad, Hercules, CA, USA) at $80 \mathrm{~V}$ for $2.5 \mathrm{~h}$. The gel was stained for $20 \mathrm{~min}$ by adding Coomassie blue dye (R-250, Sigma-Aldrich, St. Louis, CA, USA) and 20\% methanol. The sample was de-stained by adding $5 \%$ acetic acid (Sigma-Aldrich, St. Louis, CA, USA), and then bands were compared with standard protein markers (Benchmark Protein Ladder, Thermo Fisher Scientific Inc. Waltham, MA USA) in the electro photogram (Bio-Rad, Hercules, CA, USA).

\subsection{Bioaccumulation Index and Tolerance Index (TI) Determination}

The bioaccumulation index was analyzed by measuring the number of heavy metals accumulated in grown plants following the previous method [34] with slight modification. The bioaccumulation index was calculated by using the following formula:

$$
\text { Bioaccumulation index }(\mu \mathrm{g} / \mathrm{g})=\mathrm{C}^{\text {plant }} / \mathrm{C}^{\text {water }}
$$

$\mathrm{C}^{\text {plant }}=$ Concentration of HMs in rice plant

$\mathrm{C}^{\text {water }}=$ Concentration of HMs in water 
The tolerance index of plants was measured by using the protocol of Wu et al. [35] with slight modification. The following formula was used to estimate the tolerance index (\%) with slight modification.

$$
\text { TI }(\%)=(\text { Dry weight of treated plants } / \text { Dry weight of control plants } \times 100)
$$

\subsection{Statistical Analysis}

The data were subjected to one-way ANOVA by using statistix 9 software (v.10, Informer Technologies, Inc., Los Angeles, CA, USA). Means were separated by following the least significance difference (LSD) at $p \leq 0.05$.

\section{Results}

\subsection{ZnO NPs Interaction with Bacteria Improved the Removal Efficiency of HMs}

In order to check the synergistic effect of ZnO NPs along with bacterial strains ( $B$. cereus and L. macroides) in remediating HMs, we first wanted to determine the potential effect(s) of ZnO NPs on bacteria at different $\mathrm{pH}(4,5,6,7,8,9$ and 10) and contact time $(0,30,60,90$ and $120 \mathrm{~min})$ in batch culture experiments (Figure 1). Results revealed that maximum remediation of $\mathrm{Pb}, \mathrm{Cd}, \mathrm{Cr}$, and $\mathrm{Cu}$ was observed at lower concentration $(5 \mathrm{mg} / \mathrm{L})$ of $\mathrm{ZnO} N P s$ with B. cereus $(98,89,90$ and $73 \%)$ and L. macroides $(93,80,73$ and $59 \%)$ at $\mathrm{pH} 8$, as compared with individual treatments of B. cereus (83 and 70\%) and L. macroides (60 and $65 \%$ ), respectively (Figure 2). Remediation efficiency was further observed at different time intervals $(0,30,60,90$ and $120 \mathrm{~min})$. Maximum removal efficiency was observed at $90 \mathrm{~min}$ time interval as compared with other conditions. Results revealed that the synergistic effect of $B$. cereus with $5 \mathrm{mg} / \mathrm{L} \mathrm{ZnO}$ NPs showed maximum remediation efficiency ( 85 and 80, 70 and $60 \%$ ) of $\mathrm{Pb}, \mathrm{Cd}, \mathrm{Cr}$, and $\mathrm{Cu}$ as compared with individual treatments of $\mathrm{B}$. cereus ( 80 and 60\%) and L. macroides (55 and 50\%), respectively (Figures 3 and 4).

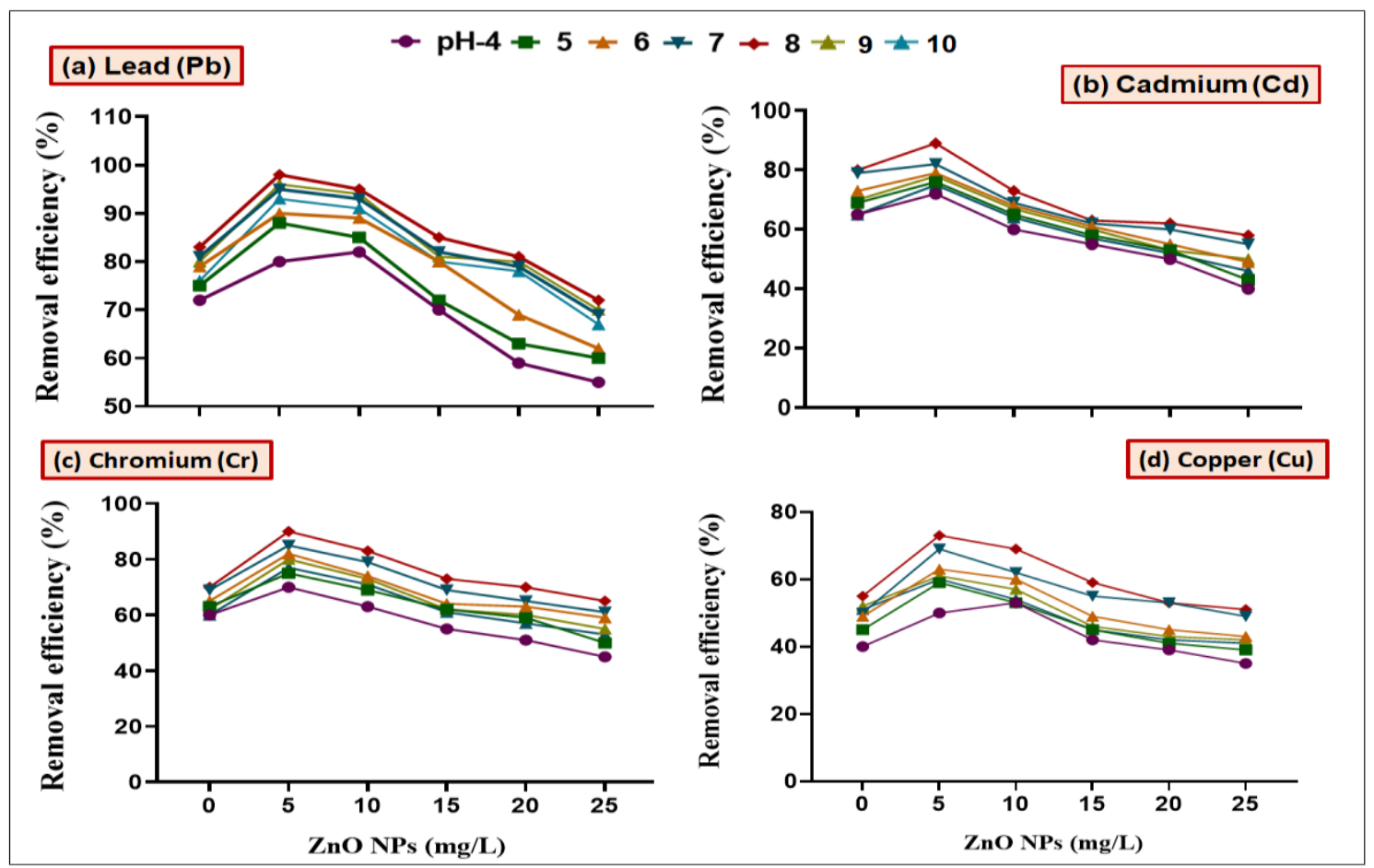

Figure 1. Synergistic effect of B. cereus and ZnO NPs $(5,10,15,20$ and $25 \mathrm{mg} / \mathrm{L})$ on the removal efficiency of (a) Lead (Pb), (b) Cadmium (Cd), (c) Chromium (Cr) and (d) Copper from the media amended with heavy metal at different $\mathrm{pH}(4,5,6,7$, 8,9 and 10). 


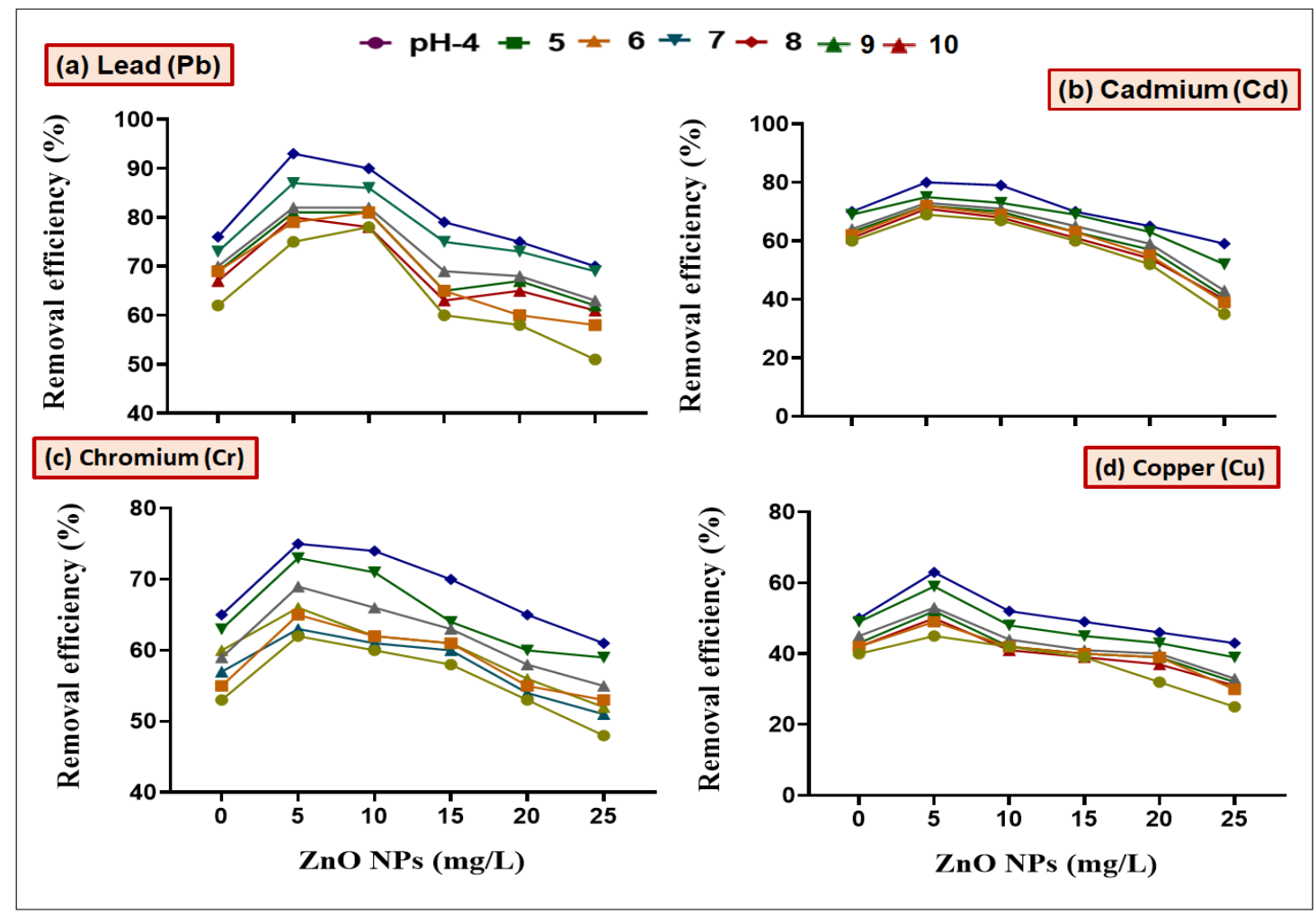

Figure 2. Synergistic effect of L. macroides and ZnO NPs (5, 10, 15, 20 and $25 \mathrm{mg} / \mathrm{L}$ ) on the removal efficiency of (a) Lead $(\mathrm{Pb}),(\mathbf{b})$ Cadmium $(\mathrm{Cd}),(\mathbf{c})$ Chromium $(\mathrm{Cr})$ and $(\mathbf{d})$ Copper from the media amended with heavy metal at different $\mathrm{pH}(4,5$, $6,7,8,9$ and 10).

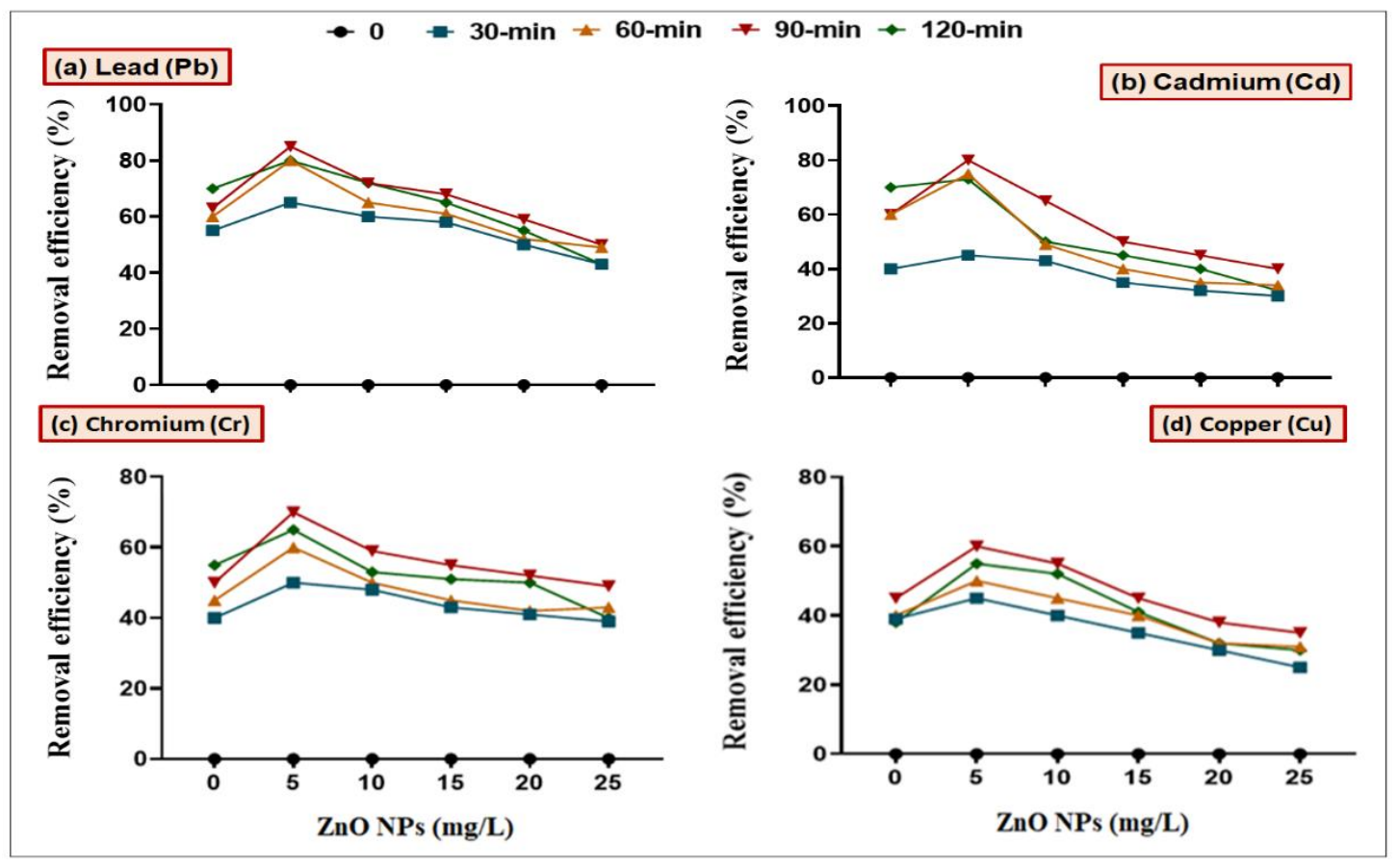

Figure 3. Synergistic effect of B. cereus and ZnO NPs (5, 10, 15, 20 and $25 \mathrm{mg} / \mathrm{L})$ on the removal efficiency of (a) Lead (Pb), (b) Cadmium (Cd), (c) Chromium (Cr) and (d) Copper from the media amended with heavy metal at different time intervals $(0,30,60,90$ and $120 \mathrm{~min})$. 


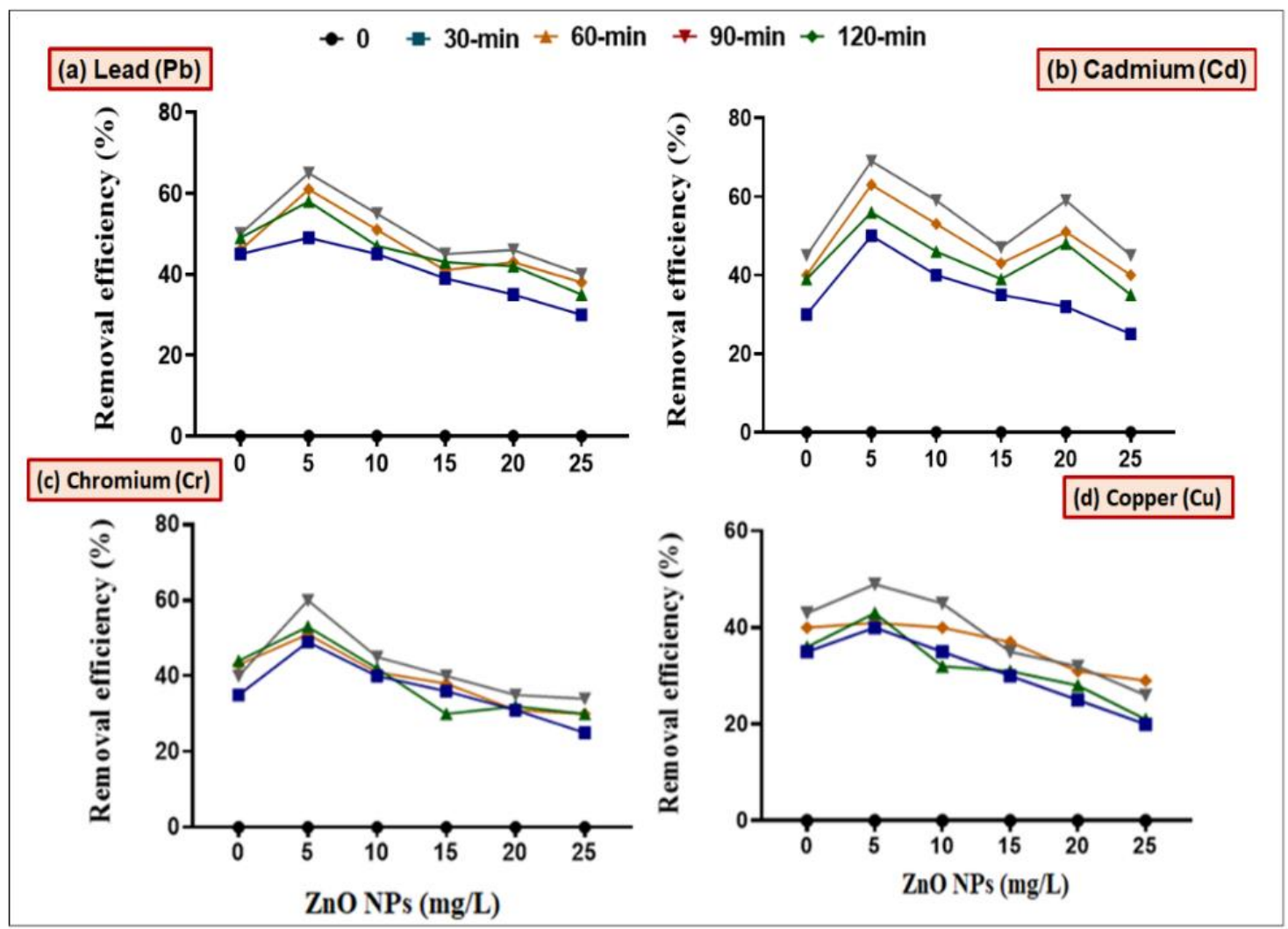

Figure 4. Synergistic effect of Lysinibacillus macrolides and ZnO NPs (5, 10, 15, 20 and $25 \mathrm{mg} / \mathrm{L})$ on the removal efficiency of (a) Lead ( $\mathrm{Pb}$ ), (b) Cadmium (Cd), (c) Chromium (Cr) and (d) Copper from the media amended with heavy metal at different time intervals $(0,30,60,90$ and $120 \mathrm{~min})$.

\section{2. $\mathrm{ZnO} \mathrm{NPs}$ Interaction with Bacteria Improved the Removal Efficiency of HMs from} Polluted Water

We had observed that $\mathrm{ZnO} N P$ s at lower concentrations, along with bacteria, efficiently remediate $\mathrm{HMs}$ from the media amended with heavy metals at neutral $\mathrm{pH}(90 \mathrm{~min})$. We further determined the effect of $\mathrm{ZnO}$ NPs at lower concentrations along with bacteria on polluted water. For this purpose, both bacterial strains (B. cereus and L. macroides) along with NPs were applied on HM contaminated water. Results revealed that maximum $\mathrm{HMs}(\mathrm{Pb}(0.24 \mathrm{mg} / \mathrm{L}), \mathrm{Cd}(1.40 \mathrm{mg} / \mathrm{L}), \mathrm{Cr}(1.26 \mathrm{mg} / \mathrm{L})$ and $\mathrm{Cu}(2.02 \mathrm{mg} / \mathrm{L})$ contents were observed in non-treated polluted water. It was observed that $B$. cereus along with lower concentrations $(10 \mathrm{mg} / \mathrm{L})$ of $\mathrm{ZnO}$ NPs revealed a maximum reduction $(0.12,1.25,1.15$ and $1.08 \mathrm{mg} / \mathrm{L})$ of $\mathrm{HMs}(\mathrm{Pb}, \mathrm{Cd}, \mathrm{Cr}$ and $\mathrm{Cu} \mathrm{mg} / \mathrm{L})$. On the contrary, higher concentrations $(25 \mathrm{mg} / \mathrm{L})$ of $\mathrm{ZnO}$ NPs with B. cereus $(0.18,1.29,1.22$ and $1.29 \mathrm{mg} / \mathrm{L})$ and L. macroides $(0.20,1.32,1.23$ and $1.21 \mathrm{mg} / \mathrm{L})$ showed a non-significant effect in $\mathrm{HM}(\mathrm{Pb}, \mathrm{Cd}, \mathrm{Cr}$ and $\mathrm{Cu})$ remediation (Table 1). 
Table 1. Synergistic effect of the bacterial strains (B. cereus and L. macroides) and ZnO NPs (5, 10, 15, 20 and $25 \mathrm{mg} / \mathrm{L}) \mathrm{on}$ the polluted water sample collected from Hayatabad Industrial Estate (HIE), Pakistan.

\begin{tabular}{|c|c|c|c|c|c|c|c|c|}
\hline \multirow{2}{*}{$\begin{array}{c}\text { Treatments } \\
\text { ZnO NPs }\end{array}$} & \multicolumn{2}{|c|}{ Lead $(0.24 \mathrm{mg} / \mathrm{L})$} & \multicolumn{2}{|c|}{ Cadmium $(1.40 \mathrm{mg} / \mathrm{L})$} & \multicolumn{2}{|c|}{ Chromium (1.26 mg/L)) } & \multicolumn{2}{|c|}{ Copper (2.02 mg/L) } \\
\hline & B. cereus & L. macroides & B. cereus & L. macroides & B. cereus & L. macroides & B. cereus & L. macroides \\
\hline $0 \mathrm{mg} / \mathrm{L}$ & $0.20+0.1^{\mathrm{ab}}$ & $0.21+0.3^{\text {ef }}$ & $1.33+0.2^{\mathrm{ab}}$ & $1.35+0.3^{b c}$ & $1.23+0.2^{\mathrm{cd}}$ & $1.19+0.3^{\mathrm{fg}}$ & $1.18+0.21 b c$ & $1.17+0.21^{c}$ \\
\hline $5 \mathrm{mg} / \mathrm{L}$ & $0.11+0.2^{b c}$ & $0.14+0.4^{\mathrm{fg}}$ & $1.22+0.3^{\mathrm{cd}}$ & $1.25+0.1^{\mathrm{cd}}$ & $1.11+0.3^{\mathrm{fg}}$ & $1.10+0.4 \mathrm{ef}^{\mathrm{f}}$ & $1.11+0.21^{\mathrm{cd}}$ & $1.12+0.21^{\mathrm{cde}}$ \\
\hline $10 \mathrm{mg} / \mathrm{L}$ & $0.12+0.3^{c}$ & $0.15+0.2 \mathrm{gh}$ & $1.25+0.1^{\text {cde }}$ & $1.26+0.2^{\mathrm{cd}}$ & $1.15+0.4^{\text {efg }}$ & $1.16+0.3 \mathrm{gh}$ & $1.08+0.21^{\text {cde }}$ & $1.09+0.21^{\mathrm{cd}}$ \\
\hline $15 \mathrm{mg} / \mathrm{L}$ & $0.15+0.1^{\mathrm{cd}}$ & $0.18+0.1^{\text {efg }}$ & $1.27+0.2^{\mathrm{cd}}$ & $1.28+0.3^{c}$ & $1.17+0.5^{\mathrm{bcd}}$ & $1.18+0.2^{\mathrm{fg}}$ & $1.12+0.21 \mathrm{bc}$ & $1.13+0.21 \mathrm{bcd}$ \\
\hline $20 \mathrm{mg} / \mathrm{L}$ & $0.18+0.2^{b c}$ & $0.19+0.2^{\mathrm{fg}}$ & $1.29+0.3^{\mathrm{ab}}$ & $1.30+0.4^{\mathrm{bc}}$ & $1.21+0.3^{b c}$ & $1.22+0.1^{c}$ & $1.15+0.21^{\mathrm{a}}$ & $1.16+0.21 \mathrm{abc}$ \\
\hline $25 \mathrm{mg} / \mathrm{L}$ & $0.18+0.1^{a b c}$ & $0.20+0.3^{\mathrm{cd}}$ & $1.29+0.4^{\mathrm{ac}}$ & $1.32+0.2^{\mathrm{ab}}$ & $1.22+0.3^{\mathrm{ab}}$ & $1.23+0.2^{\mathrm{cd}}$ & $1.19+0.21^{\mathrm{ab}}$ & $1.21+0.21 \mathrm{ab}$ \\
\hline
\end{tabular}

Different alphabets appeared in superscript on each number showed statistically significant at $5 \%$ probability level.

\subsection{ZnO NPs Interaction with Bacteria Reduced HMs Uptake in Plant Tissues \\ 3.3.1. Heavy Metals Contents in Plant Tissue (Leaf, Shoot and Root)}

Maximum accumulation of $\mathrm{Pb}, \mathrm{Cd}, \mathrm{Cr}$, and $\mathrm{Cu}$ was observed in plants grown in $\mathrm{HM}$ polluted, as compared with combined (Bacteria-ZnO NPs), treated plants. Maximum $\mathrm{Pb}$ content was observed in leaf, shoot and root $(0.065,0.075$ and $0.093 \mathrm{mg} / \mathrm{g})$ in plants grown in HM contaminated water while plant grown in combined treatments of B. cereus $(0.013$, 0.014 and $0.017 \mathrm{mg} / \mathrm{g})$ and L. macroides $(0.014,0.015$ and $0.018 \mathrm{mg} / \mathrm{g})$ at $5 \mathrm{mg} / \mathrm{L} \mathrm{ZnO} \mathrm{NPs}$ showed less accumulation of HMs as compared with individual treatment; B. cereus ( 0.053 , 0.054 and $0.075 \mathrm{mg} / \mathrm{g}$ ) and L. macroides $(0.055,0.064$ and $0.080 \mathrm{mg} / \mathrm{g})$ without ZnO NPs respectively (Figure 5). Cr content was maximum in leaf, shoot and root $(0.0069,0.0075$ and $0.0091 \mathrm{mg} / \mathrm{g}$ ) in plants grown in HM polluted water. Plant raised from seeds primed with B. cereus $(0.006,0.0065$ and $0.007 \mathrm{mg} / \mathrm{g})$ and L. macroides $(0.007,0.007$ and $0.008 \mathrm{mg} / \mathrm{g}$ ) grown in $5 \mathrm{mg} / \mathrm{L} \mathrm{ZnO}$ NPs-containing polluted water showed less $\mathrm{Cr}$ content as compared with individual treatments; B. cereus $(0.001,0.002$ and $0.008 \mathrm{mg} / \mathrm{g})$ and L. macroides $(0.006$, 0.008 and $0.009 \mathrm{mg} / \mathrm{g}$ ) without ZnO NPs treatments (Figure 5).

Results also revealed that $\mathrm{Cd}$ content was high in plant tissue (leaf, shoot, and root) $(0.0090,0.0093$ and $0.0097 \mathrm{mg} / \mathrm{g})$ grown in HM polluted water. Plants primed with B. cereus $(0.0021,0.0022,0.0024 \mathrm{mg} / \mathrm{g})$ and L. macroides $(0.0016,0.0017$ and $0.0018 \mathrm{mg} / \mathrm{g})$ grown in polluted water containing $5 \mathrm{mg} / \mathrm{L} \mathrm{ZnO}$ NPs showed less Cd content as compared with individual plants raised from seeds primed with B. cereus $(0.0070,0.0071$ and $0.0074 \mathrm{mg} / \mathrm{g}$ ) and L. macroides (0.0074, 0.0078 and $0.008 \mathrm{mg} / \mathrm{g}$ ) without $\mathrm{ZnO}$ NPs treatments (Figure 5). $\mathrm{Cu}$ content was high in leaf, shoot and root $(0.075,0.08$ and $0.121 \mathrm{mg} / \mathrm{g})$ of plant grown in HM polluted water. Plants raised from seeds primed with B. cereus $(0.0049,0.053$ and $0.054 \mathrm{mg} / \mathrm{g}$ ) and L. macroides $(0.054,0.055$ and $0.057 \mathrm{mg} / \mathrm{g}$ ) grown in polluted water containing $5 \mathrm{mg} / \mathrm{L} \mathrm{ZnO}$ NPs showed less $\mathrm{Cu}$ content as compared with plants primed with B. cereus $(0.076,0.086$ and $0.089 \mathrm{mg} / \mathrm{g})$ and L. macroides $(0.074,0.084$ and $0.09 \mathrm{mg} / \mathrm{g})$ without ZnO NPs (Figure 5d). 


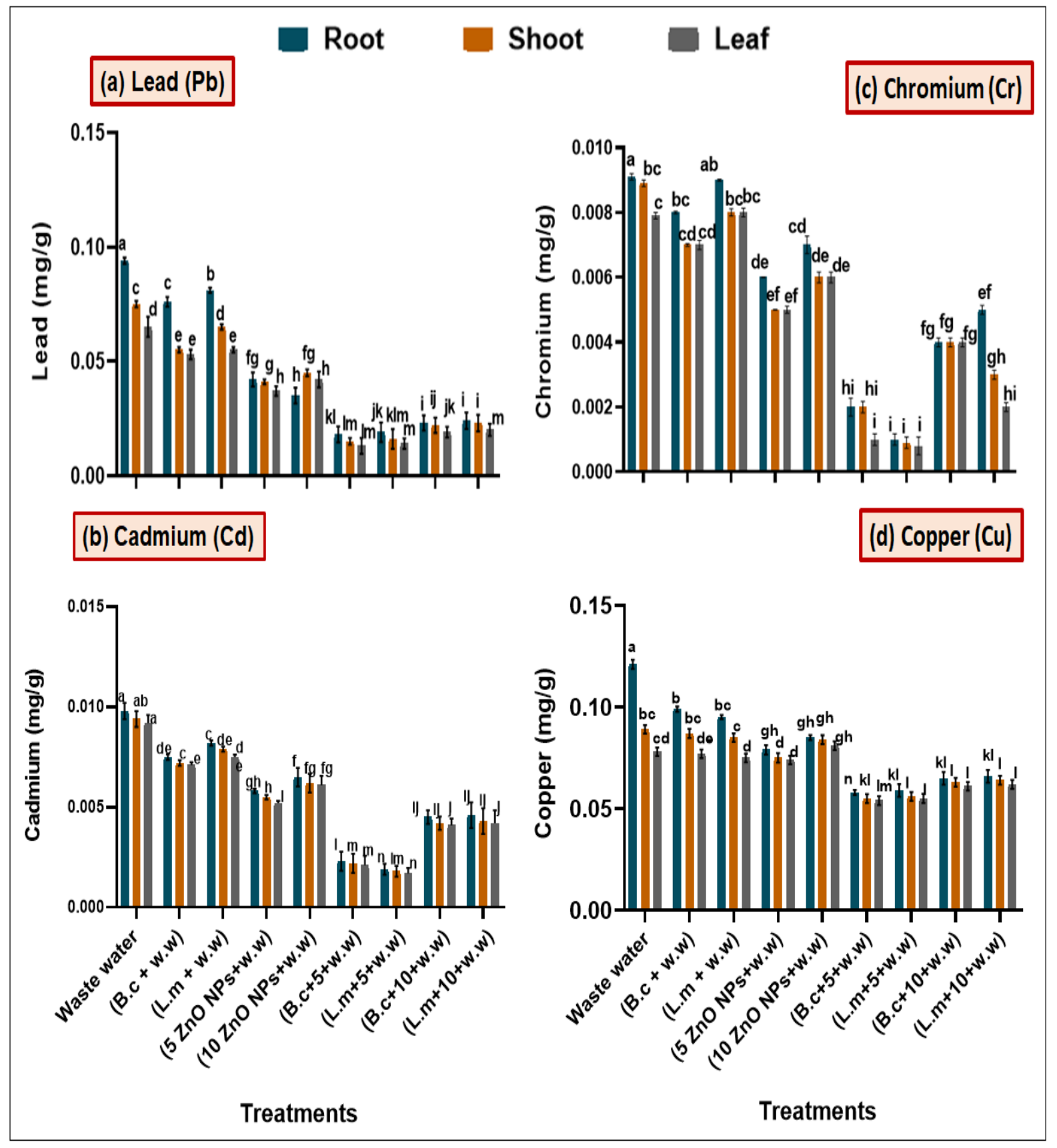

Figure 5. Synergistic effect of the bacterial strains (B. cereus and L. macroides) and ZnO NPs (5 and $10 \mathrm{mg} / \mathrm{L}$ ) on heavy metals (a) Lead (Pb), (b) Cadmium (Cd), (c) Chromium (Cr) and (d) Copper (Cu) contents in root, shoot and leaf of rice grown in heavy metal contaminated water. Error bars show means of standard error ( \pm S.E.) of three replicates $(n=3)$. Different alphabets appeared in superscript on each number showed statistically significant at $5 \%$ probability level.

\subsubsection{Total Heavy Metal Uptake, and Remediation Percentage in Polluted Water}

Plants raised from bacterial primed seeds grown at the lower concentration of $\mathrm{ZnO}$ NPs revealed a lower uptake of HM content as compared with control treatments (Table 2). Maximum uptake of $\mathrm{HMs}(\mathrm{Pb}, \mathrm{Cd}, \mathrm{Cr}$ and $\mathrm{Cu})$ was observed in plants grown in $\mathrm{HM}$ contaminated water $(0.211,0.028,0.025$ and $0.014 \mathrm{mg} / \mathrm{g})$. Synergistic treatment of seeds priming with B. cereus $(0.046,0.006,0.005$ and $0.167 \mathrm{mg} / \mathrm{g})$ and L. macroides $(0.049,0.005$, 0.006 and $0.171 \mathrm{mg} / \mathrm{g}$ ) and grown in polluted water containing $5 \mathrm{mg} / \mathrm{L} \mathrm{ZnO} \mathrm{NPs} \mathrm{revealed}$ minimum uptake of HMs as compared with individual treatment of B. cereus $(0.184,0.021$, 0.022 and $0.263 \mathrm{mg} / \mathrm{g}$ ) and L. macroides $(0.201,0.023,0.025$ and $0.255 \mathrm{mg} / \mathrm{g}$ ) (Table 2). 


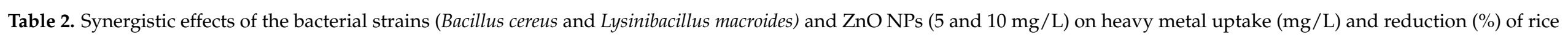
seedling grown in HM polluted water.

\begin{tabular}{|c|c|c|c|c|c|c|c|c|c|c|c|c|}
\hline \multirow[t]{2}{*}{ Treatments } & \multicolumn{3}{|c|}{$\begin{array}{c}\text { Lead } \\
(1.738 \mathrm{mg} / \mathrm{L})\end{array}$} & \multicolumn{3}{|c|}{$\begin{array}{c}\text { Cadmium } \\
(0.298 \mathrm{mg} / \mathrm{L})\end{array}$} & \multicolumn{3}{|c|}{$\begin{array}{c}\text { Chromium } \\
(0.187 \mathrm{mg} / \mathrm{L})\end{array}$} & \multicolumn{3}{|c|}{$\begin{array}{c}\text { Copper } \\
(0.581 \mathrm{mg} / \mathrm{L})\end{array}$} \\
\hline & $\begin{array}{c}\text { Water } \\
\text { Analysis } \\
(\mathrm{mg} / \mathrm{L})\end{array}$ & $\begin{array}{l}\text { Plant } \\
\text { Uptake } \\
\text { (mg/L) }\end{array}$ & $\begin{array}{c}\text { Remediation } \\
(\%)\end{array}$ & $\begin{array}{c}\text { Water } \\
\text { Analysis } \\
(\mathrm{mg} / \mathrm{L})\end{array}$ & $\begin{array}{c}\text { Plant } \\
\text { Uptake } \\
\text { (mg/L) }\end{array}$ & $\begin{array}{c}\text { Remediation } \\
(\%)\end{array}$ & $\begin{array}{c}\text { Water } \\
\text { Analysis } \\
(\mathrm{mg} / \mathrm{L})\end{array}$ & $\begin{array}{c}\text { Plant } \\
\text { Uptake } \\
\text { (mg/L) }\end{array}$ & $\underset{(\%)}{\text { Remediation }}$ & $\begin{array}{c}\text { Water } \\
\text { Analysis } \\
\text { (mg/L) }\end{array}$ & $\begin{array}{l}\text { Plant } \\
\text { Uptake } \\
\text { (mg/L) }\end{array}$ & $\begin{array}{c}\text { Remediation } \\
(\%)\end{array}$ \\
\hline Polluted water & 1.645 & 0.234 & 9.3 & 0.296 & 0.028 & 2.84 & 0.161 & 0.025 & 2.59 & 0.498 & 0.288 & 8.3 \\
\hline Bacillus cereus (B.C.) & 1.623 & 0.184 & 11.5 & 0.219 & 0.0218 & 7.9 & 0.154 & 0.022 & 3.3 & 0.465 & 0.263 & 11.6 \\
\hline Lysinibacillus macroides (L.M.) & 1.633 & 0.201 & 10.5 & 0.221 & 0.0236 & 7.7 & 0.156 & 0.025 & 3.1 & 0.476 & 0.255 & 10.5 \\
\hline $5 \mathrm{mg} / \mathrm{L} \mathrm{ZnO} \mathrm{NPs}$ & 1.564 & 0.12 & 17.4 & 0.165 & 0.0165 & 13.3 & 0.112 & 0.016 & 7.5 & 0.421 & 0.228 & 16 \\
\hline$(5+$ B.C. $)$ & 1.32 & 0.046 & 41.8 & 0.09 & 0.0066 & 20.8 & 0.057 & 0.005 & 13 & 0.321 & 0.167 & 26 \\
\hline$(5+$ L.M.) & 1.35 & 0.049 & 38.8 & 0.12 & 0.0054 & 17.8 & 0.059 & 0.0027 & 12.8 & 0.356 & 0.17 & 22.5 \\
\hline$(10+$ B.C. $)$ & 1.38 & 0.064 & 35.8 & 0.112 & 0.0128 & 18.6 & 0.078 & 0.012 & 10.9 & 0.376 & 0.189 & 20.5 \\
\hline$(10+$ L.M. $)$ & 1.39 & 0.068 & 34.8 & 0.125 & 0.0131 & 17.3 & 0.089 & 0.01 & 9.8 & 0.399 & 0.192 & 18.2 \\
\hline
\end{tabular}


Water analysis revealed that bacteria-NP combined treatments significantly decreased the HM content in polluted water as compared with individual treatments (Table 2). Maximum uptake of $\mathrm{HMs}(\mathrm{Pb}, \mathrm{Cd}, \mathrm{Cr}$ and $\mathrm{Cu}$ ) was observed in polluted water (without treated) samples $(1.645,0.269,0.161$ and $0.498 \mathrm{mg} / \mathrm{L})$; while $\mathrm{HMs}(\mathrm{Pb}, \mathrm{Cd}, \mathrm{Cr}$ and $\mathrm{Cu})$ content were lowered in a plant grown from seeds primed with B. cereus $(1.321,0.091,0.057$ and $0.321 \mathrm{mg} / \mathrm{L}$ ) and L. macroides (1.351, 0.121, 0.059 and $0.356 \mathrm{mg} / \mathrm{L})$ in polluted water containing $5 \mathrm{mg} / \mathrm{L} \mathrm{ZnO}$ NPs as compared with individual treatments; B. cereus (1.623, $0.219,0.154$ and $0.465 \mathrm{mg} / \mathrm{L})$ and L. macroides $(1.633,0.221,0.156$ and $0.470 \mathrm{mg} / \mathrm{L})$ without ZnO NPs treatments respectively (Table 2).

Maximum remediation of HMs was observed in synergistic (bacteria along with 5 and $10 \mathrm{mg} / \mathrm{L} \mathrm{ZnO}$ NPs) treated plants of seeds as compared with HM grown plants (9.3, $2.84,2.59$ and $8.3 \mathrm{mg} / \mathrm{L}$ ) (Table 2). Maximum reduction of metals ( $\mathrm{Pb}, \mathrm{Cd}, \mathrm{Cr}$ and $\mathrm{Cu}$ ) was observed in the synergistic treatment of seeds primed with $B$. cereus $(41.8,20.8,13$ and 2.6) and L. macroides $(38.5,17.8,12.8$ and $22.5 \mathrm{mg} / \mathrm{L})$ and grown in polluted water containing $5 \mathrm{mg} / \mathrm{L} \mathrm{ZnO}$ NPs as compared with individual treatments of $B$. cereus $(11.5,7.9,3.3$ and 11.6) and L. macroides (10.5, 7.7, 3.1 and 10.5) (Table 2).

\subsection{Concentrationof Low Molecular Weight Polypeptide Metallothioneins (MTs)}

It is evident from the earlier section that ZnO NPs and bacteria combined treatments, at lower concentrations, improved plant growth under HM stress. In order to prove their role in proteomic level, we determined metallothioneins (MTs) content, as mentioned in materials and methods. It is clear from Figure 6 that the synergistic effect of bacterial strains and ZnO NPs showed minimum MTs content under HMs stress as compared to the individual treatments of bacteria and ZnO NPs. Plants grown in HM contaminated water showed maximum $0.155 \mu \mathrm{mol}$ MTs content. On the contrary, plants raised from seeds primed with $B$. cereus and L. macroides grown in polluted water containing $5 \mathrm{mg} / \mathrm{L}$ ZnO NPs had the lowest MTs content $(0.0385$ and $0.059 \mu \mathrm{mol})$ compared with plants raised from primed seeds with B. cereus and L. macroides $(0.1150$ and $0.1350 \mu \mathrm{mol})$ (Figure 6A). MT concentration was also tested by using SDS PAGE. The synergistic treatment of $B$. cereus and L. macroides along with ZnO NPs at $5 \mathrm{mg} / \mathrm{L}$ in the presence of HMs showed a smaller number of bands at $7 \mathrm{kDa}$ as compared with B. cereus and L. macroides primed seeds without ZnO NPs treatments and individually grown plants at $5 \mathrm{mg} / \mathrm{L} \mathrm{ZnO} \mathrm{NPs}$ treatments, respectively (Figure 6B). 
(A)

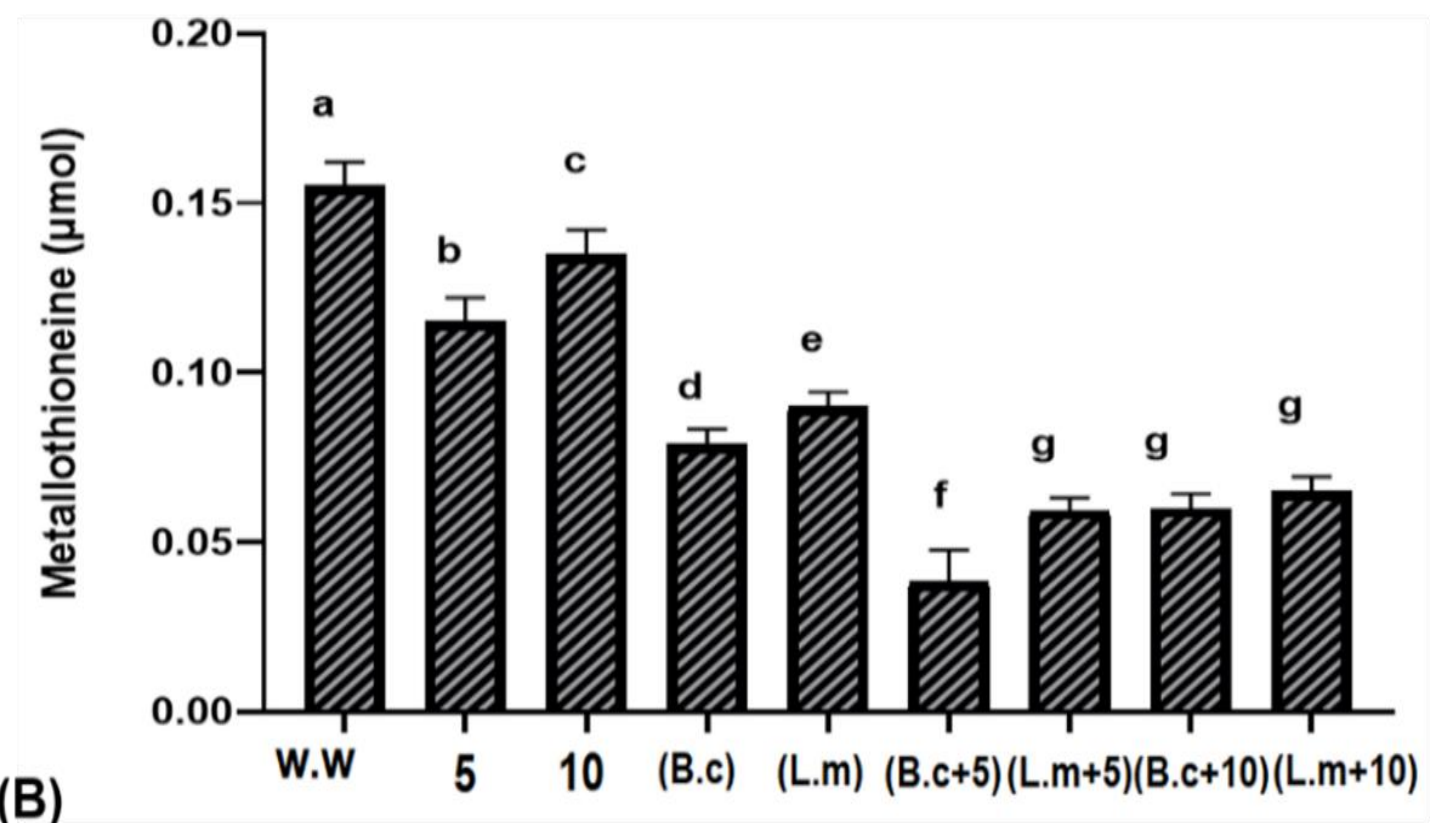

(B)

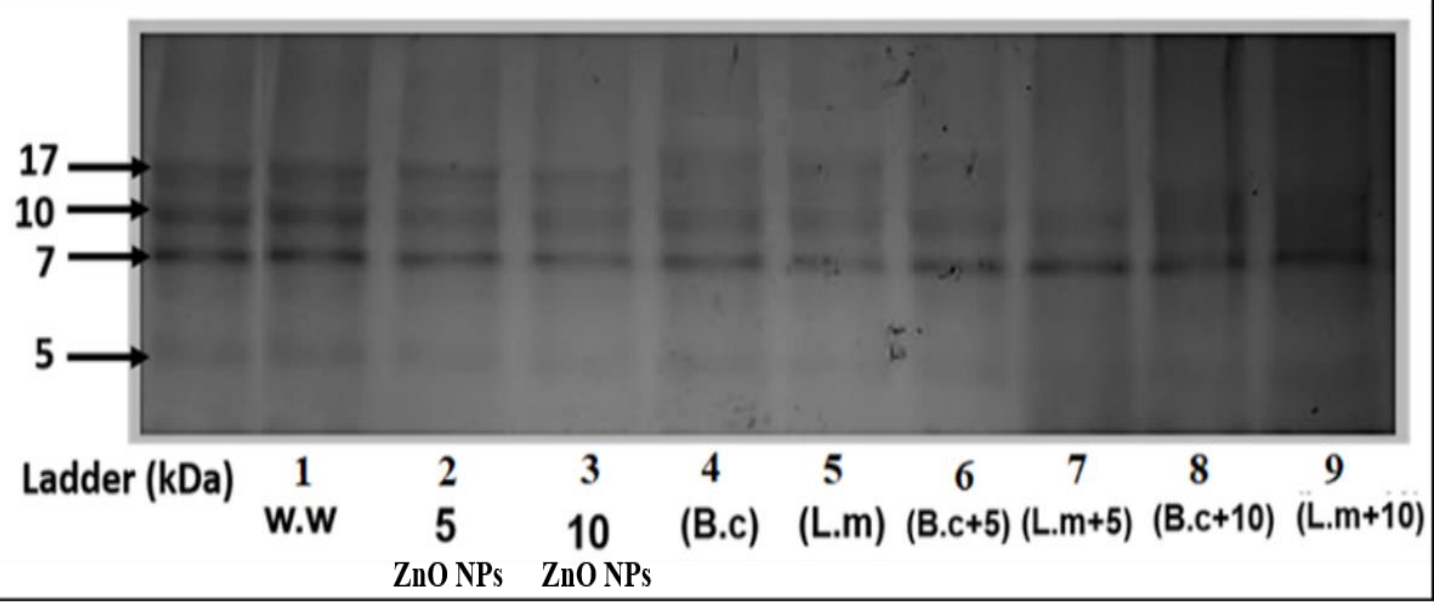

Figure 6. Synergistic effect of the bacterial strains (B. cereus and L. macroides) and ZnO NPs (5 and $10 \mathrm{mg} / \mathrm{L}$ ) on Metallothioneins (MTs) contents (A) and concentration (B) of rice plants grown in HMs contaminated water. Lane 1: w.w (Waste water)., Lane 2: 5 mg/L ZnO NPs + w.w., Lane 3: 10 mg/L ZnO NPs + w.w., Lane 4: B.c +w.w, Lane 5: L.m + w.w., Lane 6: B.c. +5 (B. cereus $+5 \mathrm{mg} / \mathrm{L} \mathrm{ZnO} \mathrm{NPs} \mathrm{+} \mathrm{w.w.).,} \mathrm{and} \mathrm{Lane} \mathrm{7:} \mathrm{L.m}+5$ (L. macroides $+5 \mathrm{mg} / \mathrm{L} \mathrm{ZnONPs}+$ w.w.), Lane 8: B.c. +10 (B. cereus $+10 \mathrm{mg} / \mathrm{L}$ ZnO NPs +w.w.) and Lane 9: L.m. + 10 (L. macroides $+10 \mathrm{mg} / \mathrm{L} \mathrm{ZnO} \mathrm{NPs} \mathrm{+} \mathrm{w.w.).} \mathrm{Error} \mathrm{bars} \mathrm{show}$ means of standard error $( \pm$ S.E. $)$ of three replicates $(n=3)$ showing statistical significance at $5 \%$ probability level (ANOVA). Different alphabets appeared in superscript on each number showed statistically significant at $5 \%$ probability level. 


\subsection{Bioaccumulation Index}

Bioaccumulation index decreased in the plants after synergistic treatment with bacteria and NPs as compared with HMs (Figure 7). Maximum accumulation of $\mathrm{Pb}, \mathrm{Cd}, \mathrm{Cr}$, and $\mathrm{Cu}$ was observed in plants grown in HMs polluted water $(0.139,0.167,0.319$ and $0.522 \mu \mathrm{g} / \mathrm{g}$ ) while minimum accumulation was observed in plants raised from seeds primed with B. cereus $(0.034,0.11,0.090$ and $0.347 \mu \mathrm{g} / \mathrm{g})$ and L. macroides $(0.36,0.108,0.05$ and $0.352 \mu \mathrm{g} / \mathrm{g}$ ) grown in polluted water contained $5 \mathrm{mg} / \mathrm{L} \mathrm{ZnO} \mathrm{NPs} \mathrm{as} \mathrm{compared} \mathrm{with}$ individual treatments of B. cereus $(0.122,0.155,0.282$ and $0.486 \mu \mathrm{g} / \mathrm{g})$ and L. macroides $(0.130$, $0.157,0.316$ and $0.467 \mu \mathrm{g} / \mathrm{g}$ ) without $\mathrm{ZnO}$ NPs (Figure 7).

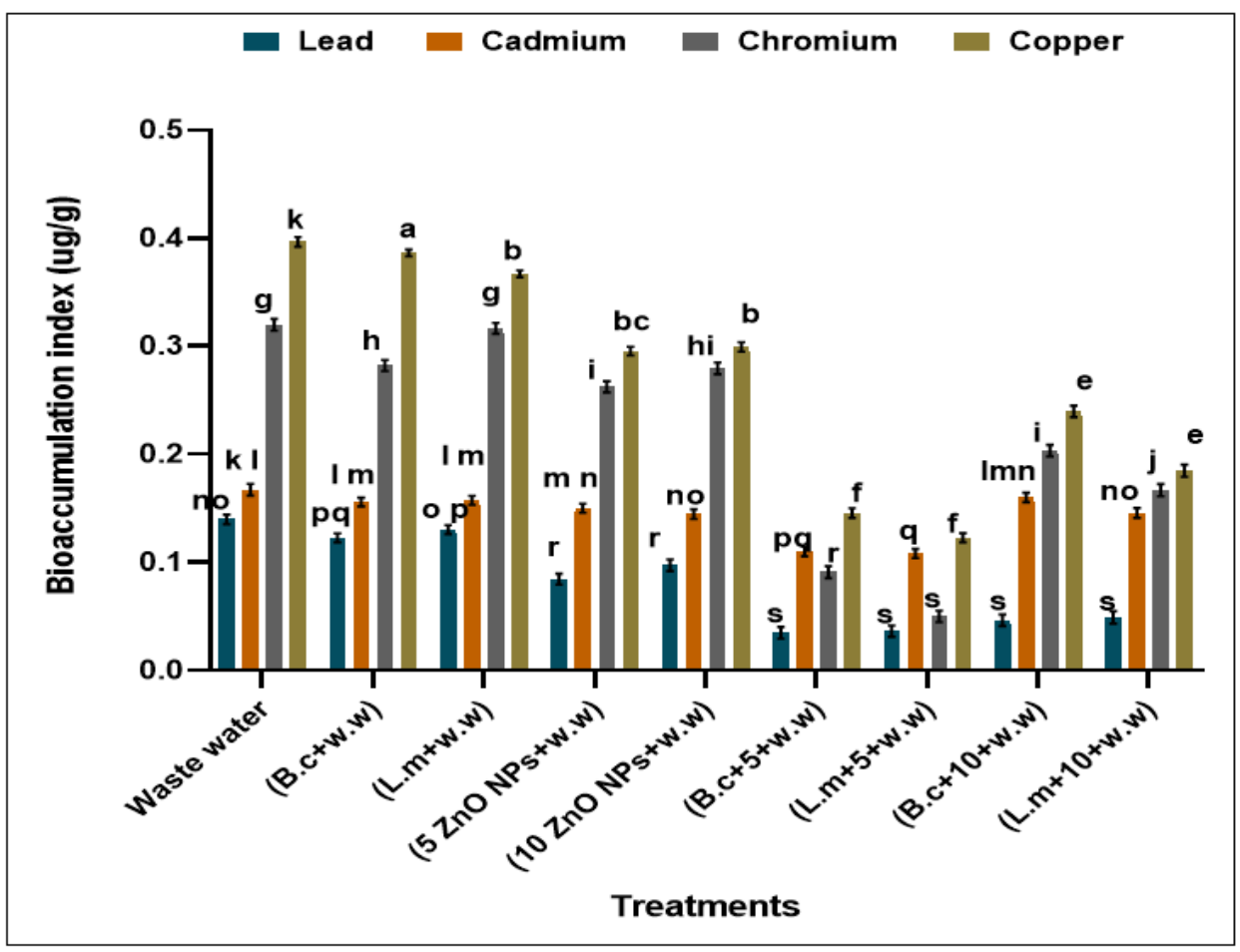

Figure 7. Bioaccumulation factor (BAF) of HMs in rice plants grown in HM polluted water. Waste water., B.c + w.w (B. cereus + waste water), L.m + w.w (L. macroides + waste water), $5 \mathrm{ZnO} \mathrm{NPs} \mathrm{+}$ w.w (5 mg/L ZnO NPs + waste water), $10 \mathrm{ZnO} \mathrm{NPs} \mathrm{+} \mathrm{w.w} \mathrm{(10} \mathrm{mg/L} \mathrm{ZnO} \mathrm{NPs} \mathrm{+} \mathrm{waste} \mathrm{water),} \mathrm{B.}$ c. $+5+$ w.w (B. cereus $+5 \mathrm{mg} / \mathrm{L} \mathrm{ZnO} \mathrm{NPs}+$ waste water), L.m $+5+\mathrm{w} \cdot \mathrm{w}$ (L. macroides $+5 \mathrm{mg} / \mathrm{L}$ ZnONPs + waste water), B.c. $+10+$ w.w (B. cereus $+10 \mathrm{mg} / \mathrm{L} \mathrm{ZnO} \mathrm{NPs} \mathrm{+} \mathrm{waste} \mathrm{water})$, L.m. +10 + w.w (L. macroides + $10 \mathrm{mg} / \mathrm{L} \mathrm{ZnO} \mathrm{NPs} \mathrm{+} \mathrm{waste} \mathrm{water).} \mathrm{Error} \mathrm{bars} \mathrm{show} \mathrm{means} \mathrm{of} \mathrm{standard} \mathrm{error}$ $( \pm$ S.E.) of three replicates $(n=3)$ showed statistical significance at $5 \%$ probability level (ANOVA). Different alphabets appeared in superscript on each number showed statistically significant at $5 \%$ probability level.

\subsection{Tolerance Index (TI)}

The tolerance index was decreased in plants grown in polluted water $(32.102 \%)$ while increased in plants grown after synergistic treatment with bacteria and NPs (Figure 8). However, as expected, maximum tolerance index was observed in the plants grown in polluted water containing $5 \mathrm{mg} / \mathrm{L} \mathrm{ZnO}$ NPs raised from seeds primed with B. cereus $(90.32 \%)$ and L. macroides $(86.54 \%)$ as compared with individual treatments of B. cereus (43.86\%) and L. macroides (40.52\%) without ZnO NPs. 


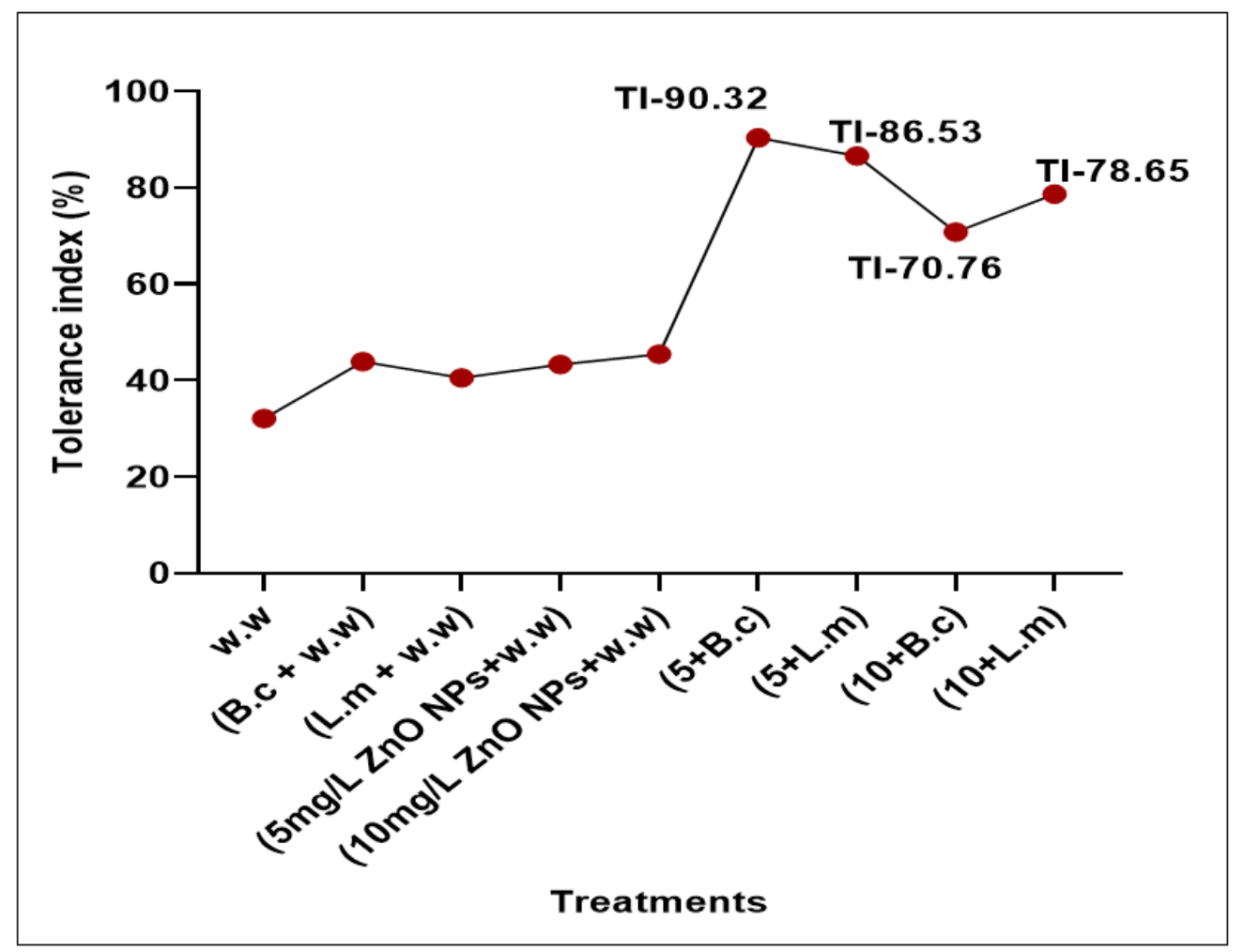

Figure 8. Tolerance index (TI) of rice plants grown in HM polluted water contained 5 and $10 \mathrm{mg} / \mathrm{L}$ $\mathrm{ZnO}$ NPs raised from seeds primed with bacterial strains (B. cereus and L. macroides). Waste water, B.c + w.w (B. cereus + waste water)., L.m + w.w (L. macroides + waste water)., $5 \mathrm{ZnO} \mathrm{NPs} \mathrm{+} \mathrm{w.w} \mathrm{(5} \mathrm{mg/L}$ ZnO NPs + waste water), $10 \mathrm{ZnO} \mathrm{NPs} \mathrm{+} \mathrm{w.w} \mathrm{(10} \mathrm{mg/L} \mathrm{ZnO} \mathrm{NPs} \mathrm{+} \mathrm{waste} \mathrm{water),} \mathrm{B.} \mathrm{c.} \mathrm{+} 5+$ w.w (B. cereus $+5 \mathrm{mg} / \mathrm{L} \mathrm{ZnO} \mathrm{NPs} \mathrm{+} \mathrm{waste} \mathrm{water).,} \mathrm{L.m} \mathrm{+} 5+$ w.w (L. macroides + $5 \mathrm{mg} / \mathrm{L}$ ZnONPs + waste water), B.c. $+10+$ w.w (B. cereus $+10 \mathrm{mg} / \mathrm{L} \mathrm{ZnO} \mathrm{NPs} \mathrm{+} \mathrm{waste} \mathrm{water),} \mathrm{L.m.}+10+$ w.w (L. macroides + $10 \mathrm{mg} / \mathrm{L} \mathrm{ZnO} \mathrm{NPs} \mathrm{+} \mathrm{waste} \mathrm{water).}$

\section{Discussion}

Pakistan has an abundance of surface and groundwater resources, but due to industrial discharge, these resources are polluted with HMs, used by farmers for irrigation [36]. HMs also affect plant growth by inhibiting the cellular process, causing low pigmentation and crop production [37]. The individual effect of NPs and bacteria was observed for the remediation of HM contaminated water, but no work so far has been reported on the combined effect of Bacillus spp. and ZnO NPs on the remediation of HMs in rice plants. ZnO NPs have received great attention worldwide and caused detoxification and transformation of metals more efficiently in plants [38]. They remain suspended in water without electrostatic forces, so they provide significant tolerance against HMs [2].

It was observed from the current findings that the removal efficiency of combined treatment of bacteria and $\mathrm{ZnO} \mathrm{NPs}(5 \mathrm{mg} / \mathrm{L}$ ) was maximum at neutral $\mathrm{pH}$ (Figures 1 and 2). This is in agreement with previous observations, where it has been shown that neutral $\mathrm{pH}$ condition made the surface of $\mathrm{ZnO}$ NPs more negative; thus electrostatic interactions between NPs and metal cations increased, which caused higher removal efficiency, while at low $\mathrm{pH}, \mathrm{HMs}$ precipitate in the form of hydroxides where hydrogen ions compete for binding with adsorbents. These results were confirmed by the findings of Xie [39] that the hydroxide ions on the functional group of NPs react with hydrous oxide at higher $\mathrm{pH}$ to produce deprotonated oxide $\left(\mathrm{MO}^{-}\right)$, while at lower $\mathrm{pH}$, the hydrous surface will be completely covered with hydrogen ions [14]. The synergistic effect is more helpful in remediating the $\mathrm{Pb}$ and $\mathrm{Cu}$ metals from polluted water. It was reported by Karn [38] that $\mathrm{ZnO}$ nanoparticles showed $85 \%$ removal efficiency of $\mathrm{Pb}$ and $\mathrm{Cu}$ metal ions in the form of metal reduction/oxidation or adsorption mechanism. The removal efficiency of HMs 
was also observed at different time intervals $(0,30,60,90$ and $120 \mathrm{~min})$. Maximum removal efficiency of HMs was observed after a 90 min time interval (Figures 3 and 4). It can be observed from the current findings that bacteria inoculation reduced the passage of metals in water, which results in low reactive oxygen species (ROS) in less time. These results were confirmed by the findings of Wang [40] that after 90 min maximum binding sites on NPs' surface were exposed, which effectively bind with metals [41].

The batch culture experiment showed that lower concentrations ( 5 and $10 \mathrm{mg} / \mathrm{L}$ ) of $\mathrm{ZnO}$ NPs improved the tolerance capacity of bacteria against heavy metals as compared with higher concentrations (Table 1). ZnO NPs at lower concentration (5 and $10 \mathrm{mg} / \mathrm{L}$ ) help bacteria in remediating HMs in polluted water. Bacillus spp. are actively involved in the biotransformation of metals and use $\mathrm{Zn}^{+2}$ ions in the range of (0.01-1 mM) as micronutrients for their growth, stabilizing the membrane, macromolecules, different steroid receptors and carbohydrate metabolism under stress conditions. These findings revealed that zinc ions are beneficial for $\mathrm{Zn}$ regulatory proteins in bacteria, so increasing the tolerance capacity of bacteria against HMs [42]. It was reported by Ashraf [43] that the bacteria strain Klebsiella variicola isolated from industrial effluents has high bio-sorption ability and maximum tolerance against HMs. A recent report has been published by Watły [44], in which it was observed that the application of titanium oxide NPs and ZnO NPs provided more active sites for HMs and increased remediation of metals.

In addition, it was observed that lower concentrations of $\mathrm{ZnO}$ NPs reduced the passage of HMs into different tissues of rice plants (Figure 5) in the presence of bacteria. Bio-priming of seeds with Bacillus species has been investigated to increase the nutritional pathway of rice under HM stress conditions [45]. Bacteria secreting plant growth-promoting metabolites extract nutrients from water by fixing nitrogen [46]. Bacillus spp. is the most notable genus used in abiotic stress tolerance in potato radish, rice, mung bean and chickpea [47]. The recent Amiard report [48] revealed that a significant reduction of HMs occurred in plants in two ways; the higher secretion of root exudates leads to higher adsorption of HMs on ZnO NPs; surface so reducing the bioavailability of metals. Low $\mathrm{pH}$ (5.4-5.8) is associated with retaining most ions at a free-standing position, while higher $\mathrm{pH}$ lowers the nutrient bioavailability. It was reported by Sharifan [49] that ZnO NPs act as bio-sorbent for the remediation of cobalt from water, used for the irrigation of crops.

Metallothionein (MTs) content in plants under HM stress is a well-known phenomenon [50]. Current research demonstrated that plants grown under HM stress had high MTs contents as compared with control plants (Figure 6). Our results showed resemblance to the findings of Khati et al. [51], who revealed that MTs content increased in plants under cadmium (Cd) stress. B. cereus and L. macroides primed seeds with ZnO NPs reduced HMs stress and lowered MT content. HM-resistant bacteria strains prevent the plant from a toxic effect and restrict their inflow in the plant. Earlier studies reported maximum MT contents in lupinus luteus L. plant under HMs stress [52].

Current findings also revealed that the number of HMs was reduced in water by bacteria-nanoparticles interaction (Table 2). It was also observed in the current study that bioaccumulation index $\mathrm{HMs}(\mathrm{Pb}, \mathrm{Cd}, \mathrm{Cr}$, and $\mathrm{Cu})$ in the plant decreased and tolerance index increased in plants raised from bacteria primed seeds after application of NPs, as compared with HM polluted water (Figure 7). Metal reduction may be due to the ability of heavy metal-resistant bacteria to immobilize the HMs in the root by different mechanisms [52]. According to Abraham [46], seed inoculation with $\mathrm{Cr}$ resistance strain P. aeruginosa reduces the amount of chromium and increases plant growth. It was reported by $\mathrm{Wu}$ [35] that seed priming with bacteria increased the germination and tolerance capacity of crops by adhering to the seeds and decreased the passage of HMs to plants. It was also reported that $\mathrm{ZnO}$ NPs have a high surface to volume ratio in reacting with metals in contaminated media and also triggers the movement of metals in biochemical pathways in plants [44]. It was investigated by Dubchak [53] that metal oxide NPs such as $\mathrm{Fe}_{3} \mathrm{O}_{4}, \mathrm{ZnO}$ and $\mathrm{CuO}$ remove the metals from aqueous solution. These results were further confirmed by Kummar et al. [29], who observed that metal oxide $\mathrm{NPs}$ such as $\mathrm{Fe}_{3} \mathrm{O}_{4}, \mathrm{ZnO}$ and $\mathrm{CuO}$ removed the 
metals from aqueous solution and increased the germination of Mung (Vignaradiata) and gram (Cicer aretinium) plants.

\section{Conclusions}

It was concluded from the current study that ZnO NPs (at lower concentrations), along with bacteria, more efficiently bind with HMs ions and remediate metals from polluted water, as compared to their individual effect. The combined effect also showed low bioaccumulation index, metallothionine (MTs) content and inhibited the passage of HMs to plant tissues by improving the plant tolerance index. The combined treatments of $\mathrm{ZnO} N \mathrm{Ns}$ and bacteria play a significant role in plant tolerance level and the removal of HMs from water.

Author Contributions: N.A.: Wrote the manuscript, carried out the experiment and performed the numerical calculations for the suggested experiment; M.J.: Author was involved in planning and supervised the work, the main conceptual ideas and proof outline, verified the statistical methods, and supervised the work; S.K.: Author help in performing the experiments; S.U.R.: Author provided critical feedback and helped to shape the research; Z.U.R., A.K. and E.S.R.: Author provided critical feedback and helped to shape the research. All authors have read and agreed to the published version of the manuscript.

Funding: The research was partly supported by a grant No. 4372 from the Higher Education commission (HEC), Pakistan.

Institutional Review Board Statement: Not applicable.

Informed Consent Statement: Not applicable.

Data Availability Statement: Not applicable.

Acknowledgments: Pir Mehr Ali Shah, Arid Agriculture University, Rawalpindi, Pakistan has been acknowledged for the provision of nanoparticles.

Conflicts of Interest: The authors declare no conflict of interest.

\section{References}

1. Azimi, A.; Azari, A.; Rezakazemi, M.; Ansarpour, M. Removal of heavy metals from industrial wastewaters: A review. Chem. Biol. Eng. Rev. 2017, 4, 37-59. [CrossRef]

2. Amin, N.; Ayaz, M.; Alam, S.; Gul, S. Heavy metals contamination through industrial effluent to irrigation water in GadoonAmazai (Swabi) and Hayatabad (Peshawar) Pakistan. J. Sci. Res. 2013, 6, 111-124. [CrossRef]

3. Randhawa, M.A.; Ahmad, G.; Anjum, F.M.; Asghar, A.; Sajid, M.W. Heavy metal contents and their daily intake in vegetables under peri-urban farming system of Multan, Pakistan. Pak. J. Agric. Sci. 2014, 51, 1-20.

4. Bangash, F.K.; Fida, M.; Fazeelat, T. Appraisal of effluents of some selected industries of Hayatabad industrial estate, Peshawar. J. Chem. Soc. Pak. 2006, 28, 16-19.

5. Nawaz, A.; Khurshid, K.; Arif, M.S.; Ranjha, A.M. Accumulation of heavy metals in soil and rice plant (Oryza sativa L.) irrigated with industrial effluents. Int. J. Agric. Biol. 2006, 8, 391-393.

6. Khan, M.U.; Malik, R.N.; Muhammad, S. Human health risk from heavy metal via food crops consumption with wastewater irrigation practices in Pakistan. Chemosphere 2013, 93, 2230-2238. [CrossRef] [PubMed]

7. Zheng, L.; Peer, T.; Seybold, V.; Lütz-Meindl, U. Pb-Induced ultrastructural alterations and subcellular localization of Pb in two species of Lespedeza by TEM-coupled electron energy loss spectroscopy. Environ. Exp. Bot. 2012, 77, 196-245. [CrossRef]

8. Prasad, M.N.V.; Hagemeyer, J.; Poschenrieder, C.; Barceló, J. Water relations in heavy metal stressed plants. In Heavy Metal Stress in Plants; Springer: Berlin/Heidelberg, Germany, 1999; pp. 138-177.

9. Amiard, J.C.; Amiard-Triquet, C.; Barka, S.; Pellerin, J.; Rainbow, P.S. Metallothioneins in aquatic invertebrates: Their role in metal detoxification and their use as biomarkers. Aquat. Toxicol. 2006, 76, 160-202. [CrossRef]

10. Fu, F.; Wang, Q. Removal of heavy metal ions from wastewaters: A review. J. Environ. Manag. 2011, 92, 407-418. [CrossRef]

11. Aruguete, D.M.; Hochella, M.F. Bacteria-nanoparticle interactions and their environmental implications. Environ. Chem. 2010, 7, 3-9. [CrossRef]

12. Dixit, R.; Wasiullah, M.D.; Pandiyan, K.; Singh, U.B.; Sahu, A.; Paul, D. Bioremediation of heavy metals from soil and aquatic environment: An overview of principles and criteria of fundamental processes. Sustainability 2015, 7, 2189-2212. [CrossRef]

13. Wang, Z.L. Zinc oxide nanostructures: Growth, properties and applications. J. Phys. Condens. Matter 2004, 16, 22-40. [CrossRef] 
14. Venkatachalam, P.; Jayaraj, M.; Manikandan, R.; Geetha, N.; Rene, E.R.; Sharma, N.C.; Sahi, S.V. Zinc oxide nanoparticles (ZnONPs) alleviate heavy metal-induced toxicity in Leucaena leucocephala seedlings: A physiochemical analysis. Plant Physiol. Biochem. 2017, 110, 59-69. [CrossRef] [PubMed]

15. Maity, A.; Natarajan, N.; Vijay, D.; Srinivasan, R.; Pastor, M.; Malaviya, D.R. Influence of metal nanoparticles (NPs) on germination and yield of oat (Avena sativa) and Berseem (Trifolium alexandrinum). Proc. Natl. Acad. Sci. India Sect. B Biol. Sci. 2018, 88, 595-607. [CrossRef]

16. Hazeem, L.J.; Bououdina, M.; Rashdan, S.; Brunet, L.; Slomianny, C.; Boukherroub, R. Cumulative effect of zinc oxide and titanium oxide nanoparticles on growth and chlorophyll a content of Picochlorumsp. Environ. Sci. Pollut. Res. 2016, 23, 2821-2830. [CrossRef] [PubMed]

17. Manke, A.; Wang, L.; Rojanasakul, Y. Mechanisms of nanoparticle-inducedoxidative stress and toxicity. Bio. Med. Res. Int. 2013, 1, 216-942.

18. Kumawat, N.; Kumar, R.; Kumar, S.; Meena, V.S. Nutrient Solubilizing Microbes (NSMs): Its role in sustainable crop production. In Agriculturally Important Microbes for Sustainable Agriculture; Springer: Singapore, 2017; pp. $25-61$.

19. Sharma, Y.C.; Srivastava, V.; Singh, V.K.; Kaul, S.N.; Weng, C.H. Nano-Adsorbents for the removal of metallic pollutants from water and wastewater. Environ. Technol. 2009, 30, 583-609. [CrossRef] [PubMed]

20. Burman, U.; Saini, M.; Kumar, P. Effect of zinc oxide nanoparticles on growth and antioxidant system of chickpea seedlings. Toxicol. Environ. Chem. 2013, 95, 605-615. [CrossRef]

21. Sharma, N.; Kumar, J.; Thakur, S.; Sharma, S.; Shrivastava, V. Antibacterial study of silver doped zinc oxide nanoparticles against Staphylococcus aureus and Bacillus subtilis. Drug Invent. Today 2013, 30, 583-609. [CrossRef]

22. Hegazi, H.A. Removal of heavy metals from wastewater using agricultural and industrial wastes as adsorbents. HBRC J. 2013, 9 , 272-286. [CrossRef]

23. Hoseinzadeh, E.; Rezaee, A.; Khorramabadi, G.S.; Azizi, S.; Yousefzadeh, A. Evaluation of photocatalytic convertion of hexavalent chromium $(\mathrm{Cr}(\mathrm{VI}))$ to trivalent chromium $(\mathrm{Cr}(\mathrm{III}))$ in the presence of zinc oxide nanoparticle from aqueous solution. J. Maz. Univ. Med. Sci. 2014, 1, 115-132.

24. Amara, U.; Shad, S.; Ilyas, N.; Manaf, A.; Raja, N.I. In vitro germination and biochemical profiling of Brassica napus in response to biosynthesised zinc nanoparticles. IET Nanobiotechnol. 2018, 13, 46-51.

25. Khattak, M.R.; Shah, G.; Naeem, R.; Fayyaz, M.; Rehman, M.; Anees, M.; Rha, E.S.; Jamil, M. Assessment of heavy metal tolerance and reduction potential of bacillus sp. isolated from the soils contaminated with industrial effluents. Fresenius Environ. Bull. 2021, $30,4391-4401$.

26. Radulescu, C.; Stihi, C.; Ionita, I.; Dulama, I.D.; Chilian, A.; Necula, C.; Chelarescu, E.D. Determination of heavy metal levels in water and therapeutic mud by atomic absorption spectrometry. Rom. J. Phys. 2014, 59, 1057-1059.

27. Bestawy, E.; Helmy, E.S.; Hussien, H.; Fahmy, M.; Amer, R. Bioremediation of heavy metal-contaminated effluent using optimized activated sludge bacteria. Appl. Water Sci. 2013, 3, 181-192. [CrossRef]

28. Salam, O.E.A.; Reiad, N.A.; ElShafei, M.M. A study of the removal characteristics of heavymetals from wastewater by low-cost adsorbents. J. Adv. Res. 2011, 2, 297-303. [CrossRef]

29. Kumar, K.Y.; Muralidhara, H.B.; Nayaka, Y.A.; Balasubramanyam, J.; Hanumanthappa, H. Hierarchically assembled mesoporous $\mathrm{ZnO}$ nanorods for the removal of lead and cadmium by using differential pulse anodic stripping voltammetric method. Powder Technol. 2013, 239, 208-216. [CrossRef]

30. Retka, J.; Maksymowicz, A.; Karmasz, D. Determination of $\mathrm{Cu}, \mathrm{Ni}, \mathrm{Zn}, \mathrm{Pb}, \mathrm{Cd}$ by ICP-MS and Hg by AAS in Plant Samples; International Atomic Energy Agency (IAEA): Vienna, Austria, 2010.

31. Palmiter, R.D. Protection against zinc toxicity by metallothionein and zinc transporter 1. Proc. Natl. Acad. Sci. USA 2004, 101, 4918-4923. [CrossRef] [PubMed]

32. Tsugama, D.; Liu, S.; Takano, T. A rapid chemical method for lysing Arabidopsis cells for protein analysis. Plant Methods 2011, 7, 11-22. [CrossRef]

33. Laemmli, U.K. Cleavage of structural proteins during the assembly of the head of bacteriophage T4. Nature 1970, 227, 680-685. [CrossRef]

34. Antonkiewicz, J.; Jasiewicz, C.; Koncewicz-Baran, M.; Sendor, R. Nickel bioaccumulation by the chosen plant species. Acta Physiol. Plant. 2016, 3, 38-41. [CrossRef]

35. Wu, L.; Li, Z.; Han, C.; Liu, L.; Teng, Y.; Sun, X.; Christie, P. Phytoremediation of soil contaminated with cadmium, copper and polychlorinated biphenyls. Int. J. Phytoremediat. 2012, 14, 570-584. [CrossRef]

36. Verma, S.; Dubey, R.S. Lead toxicity induces lipid peroxidation and alters the activities of antioxidant enzymes in growing rice plants. Plant Sci. 2003, 6, 645-655. [CrossRef]

37. Nagajyoti, P.C.; Lee, K.D.; Sreekanth, T.V.M. Heavy metals, occurrence and toxicity for plants: A review. Environ. Chem. Lett. 2010, 8, 199-216. [CrossRef]

38. Karn, B.; Kuiken, T.; Otto, M. Nanotechnology and in situ remediation: A review of the benefits and potential risks. Environ. Health Perspect. 2009, 117, 1813-1819. [CrossRef]

39. Xie, Y.; He, Y.; Irwin, P.L.; Jin, T.; Shi, X. Antibacterial activity and mechanism of action of zinc oxide nanoparticles against Campylobacter jejuni. Appl. Environ. Microbiol. 2011, 77, 2325-2331. [CrossRef] 
40. Wang, D.; Guo, Y.; Wu, C.; Yang, G.; Li, Y.; Zheng, C. Genome-Wide analysis of CCCH zinc finger family in Arabidopsis and rice. BMC Genom. 2008, 99, 44. [CrossRef]

41. Mahdavi, S.; Jalali, M.; Afkhami, A. Removal of heavy metals from aqueous solutions using $\mathrm{Fe}_{3} \mathrm{O}_{4}$, $\mathrm{ZnO}$, and CuO nanoparticles. In Nanotechnology for Sustainable Development; Springer: Cham, Switzerland, 2014; pp. 171-180.

42. Munzuroglu, O.; Geckil, H. Effects of metals on seed germination, root elongation, and coleoptile and hypocotyl growth in Triticum aestivum and Cucumis sativus. Arch. Environ. Contam. Toxicol. 2002, 43, 202-213. [CrossRef]

43. Ashraf, M.; Foolad, M.R. Roles of glycine betaine and proline in improving plant abiotic stress resistance. Environ. Exp. Bot. 2007, 59, 206-216. [CrossRef]

44. Wątły, J.; Potocki, S.; Rowińska-Żyrek, M. Zinc homeostasis at the bacteria/host interface-From coordination chemistry to nutritional immunity. Chem. Eur. J. 2016, 22, 15992-16010. [CrossRef]

45. Pandey, N.; Pathak, G.C.; Pandey, D.K.; Pandey, R. Heavy metals, Co, Ni, Cu, Zn and Cd, produce oxidative damage and evoke differential antioxidant responses in spinach. Braz. J. Plant. Physiol. 2009, 21, 103-111. [CrossRef]

46. Abraham, K.; Sridevi, R.; Suresh, B.; Damodharam, T. Effect of heavy metals (Cd, Pb, Cu) on seed germination of Arachis hypogeae L. Asian J. Plant Sci. Res. 2013, 3, 10-12.

47. Hooda, V. Phytoremediation of toxic metals from soil and wastewater. Environ. Biol. 2007, 28, 367-376.

48. Sharifan, H.; Ma, X.; Moore, J.M.C.; Habib, M.R.; Evans, C. Zinc oxide nanoparticles alleviated the bioavailability of cadmium and lead and changed the uptake of iron in hydroponically grown lettuce (Lactuca sativa L. var. Longifolia). ACS Sustain. Chem. Eng. 2019, 7, 16401-16409. [CrossRef]

49. Ahn, Y.O.; Kim, S.H.; Lee, J.; Ran Kim, H.; Lee, H.S.; Kwak, S.S. Three Brassica rapa metallothionein genes are differentially regulated under various stress conditions. Mol. Biol. Rep. 2012, 39, 2059-2070. [CrossRef]

50. Khati, W.; Ouali, K.; Mouneyrac, C.; Banaoui, A. Metallothioneins in aquatic invertebrates: Their role in metal detoxification and their use in biomonitoring. Energy Procedia 2012, 18, 784-794. [CrossRef]

51. Jaskulak, M.; Rorat, A.; Grobelak, A.; Chaabene, Z.; Kacprzak, M.; Vandenbulcke, F. Bioaccumulation, antioxidative response, and metallothionein expression in Lupinus luteus L. exposed to heavy metals and silver nanoparticles. Environ. Sci. Pollut. 2019, 26, 16040-16052. [CrossRef]

52. Amin, N.U.; Hussain, A.; Alamzeb, S.; Begum, S. Accumulation of heavy metals in edible parts of vegetables irrigated with wastewater and their daily intake to adults and children, District Mardan, Pakistan. Food Chem. 2013, 136, 1515-1523. [CrossRef]

53. Dubchak, S.; Ogar, A.; Mietelski, J.W.; Turnau, K. Influence of silver and titanium nanoparticles on arbuscular mycorrhiza colonization and accumulation of radiocaesium in Helianthus annuus. Span. J. Agric. Res. 2010, 8, 103-108. [CrossRef] 